\title{
Detrital Zircon U-Pb Data for Jurassic-Cretaceous Strata from the South-Eastern Verkhoyansk-Kolyma Orogen-Correlations to Magmatic Arcs of the North-East Asia Active Margin
}

\author{
Andrei V. Prokopiev ${ }^{1, *}$, Victoria B. Ershova ${ }^{1,2,3}$ (D) and Daniel F. Stockli ${ }^{4}$ \\ 1 Diamond and Precious Metal Geology Institute, Siberian Branch, Russian Academy of Sciences, Lenin Av. 39, \\ Yakutsk 677980, Russia; v.ershova@spbu.ru \\ 2 Institute of Earth Sciences, Saint Petersburg State University, Universitetskaya nab. 7/9, \\ St. Petersburg 199034, Russia \\ 3 Geological Institute, Russian Academy of Sciences, Moscow 109017, Russia \\ 4 Department of Geological Sciences, Jackson School of Geoscience, University of Texas at Austin, \\ Austin, TX 78712, USA; stockli@jsg.utexas.edu \\ * Correspondence: prokopiev@diamond.ysn.ru
}

\section{check for} updates

Citation: Prokopiev, A.V.; Ershova, V.B.; Stockli, D.F. Detrital Zircon U-Pb Data for Jurassic-Cretaceous Strata from the South-Eastern VerkhoyanskKolyma Orogen-Correlations to Magmatic Arcs of the North-East Asia Active Margin. Minerals 2021, 11, 291. https://doi.org/10.3390/ $\min 11030291$

Academic Editor:

Rubén Díez-Fernández

Received: 15 January 2021

Accepted: 8 March 2021

Published: 11 March 2021

Publisher's Note: MDPI stays neutral with regard to jurisdictional claims in published maps and institutional affiliations.

Copyright: (c) 2021 by the authors. Licensee MDPI, Basel, Switzerland. This article is an open access article distributed under the terms and conditions of the Creative Commons Attribution (CC BY) license (https:// creativecommons.org/licenses/by/ $4.0 /)$.

\begin{abstract}
We performed U-Pb dating of detrital zircons collected from Middle-Upper Jurassic strata of the Sugoi synclinorium and Cretaceous rocks of the Omsukchan (Balygychan-Sugoi) basin, in order to identify their provenance and correlate Jurassic-Cretaceous sedimentation of the south-eastern Verkhoyansk-Kolyma orogenic belt with various Magmatic belts of the north-east Asia active Margins. In the Middle-Late Jurassic, the Uda-Murgal Magmatic arc represented the Main source area of clastics, suggesting that the Sugoi basin is a back-arc basin. A Major shift in the provenance signature occurred during the Aptian, when granitoids of the Main (Kolyma) batholith belt, along with volcanic rocks of the Uyandina-Yasachnaya and Uda-Murgal arcs, became the Main sources of clastics deposited in the Omsukchan basin. In a final Mesozoic provenance shift, granitoids of the Main (Kolyma) batholith belt, along with volcanic and plutonic rocks of the Uyandina-Yasachnaya and Okhotsk-Chukotka arcs, became the dominant sources for clastics in the Omsukchan basin in the latest Cretaceous. A broader comparison of detrital zircon age distributions in Jurassic-Cretaceous deposits across the south-eastern Verkhoyansk-Kolyma orogen illustrates that the Sugoi and Omsukchan basins did not form along the distal eastern portion of the Verkhoyansk passive Margin, but in the Late Mesozoic back-arc basins.
\end{abstract}

Keywords: North-east Asia; Verkhoyansk-Kolyma orogen; Magmatic belts; Late Mesozoic sedimentary basins; Sugoi synclinorium; Omsukchan (Balygychan-Sugoi) basin; detrital zircons

\section{Introduction}

For almost 400 million years during the Early Paleozoic-Mesozoic, the Pacific Margin of NE Asia was characterized by the initiation, evolution, termination, and revival of Magmatic arcs in response to subduction and collisional processes along the complex, long-lived north-east Asia active Margins (Figure 1). Fragments of the Paleozoic Magmatic arcs, such as the Maya-Abkit and North-Okhotsk arcs, are scattered within continental blocks of the Kolyma-Omolon Superterrane in the central part of the Verkhoyansk-Kolyma orogenic belt. In the Mesozoic, several arc Magmatic belts formed during closure of the Oymyakon Ocean and the resulting collision of the Kolyma-Omolon Superterrane and Siberia, including the Main (Kolyma), Uyandina-Yasachnaya, Northern, and Transverse Magmatic belts (e.g., [1-12] and references therein). To the north (in present-day coordinates), the Svyatoi Nos-Oloy and New Siberian-Chukotka Magmatic belts formed during closure of the South Anyui Ocean and formation of the Novosibirsk-Chukotka orogenic belt (e.g., [2,3,5,6,11-18], and references therein). The coeval Magmatic belts also formed to the south along the 
paleo-Pacific Margin, known as the Uda-Murgal and Okhotsk-Chukotka volcanic-plutonic belts (Figure 1) (e.g., $[1,2,11,19,20]$ and references therein).

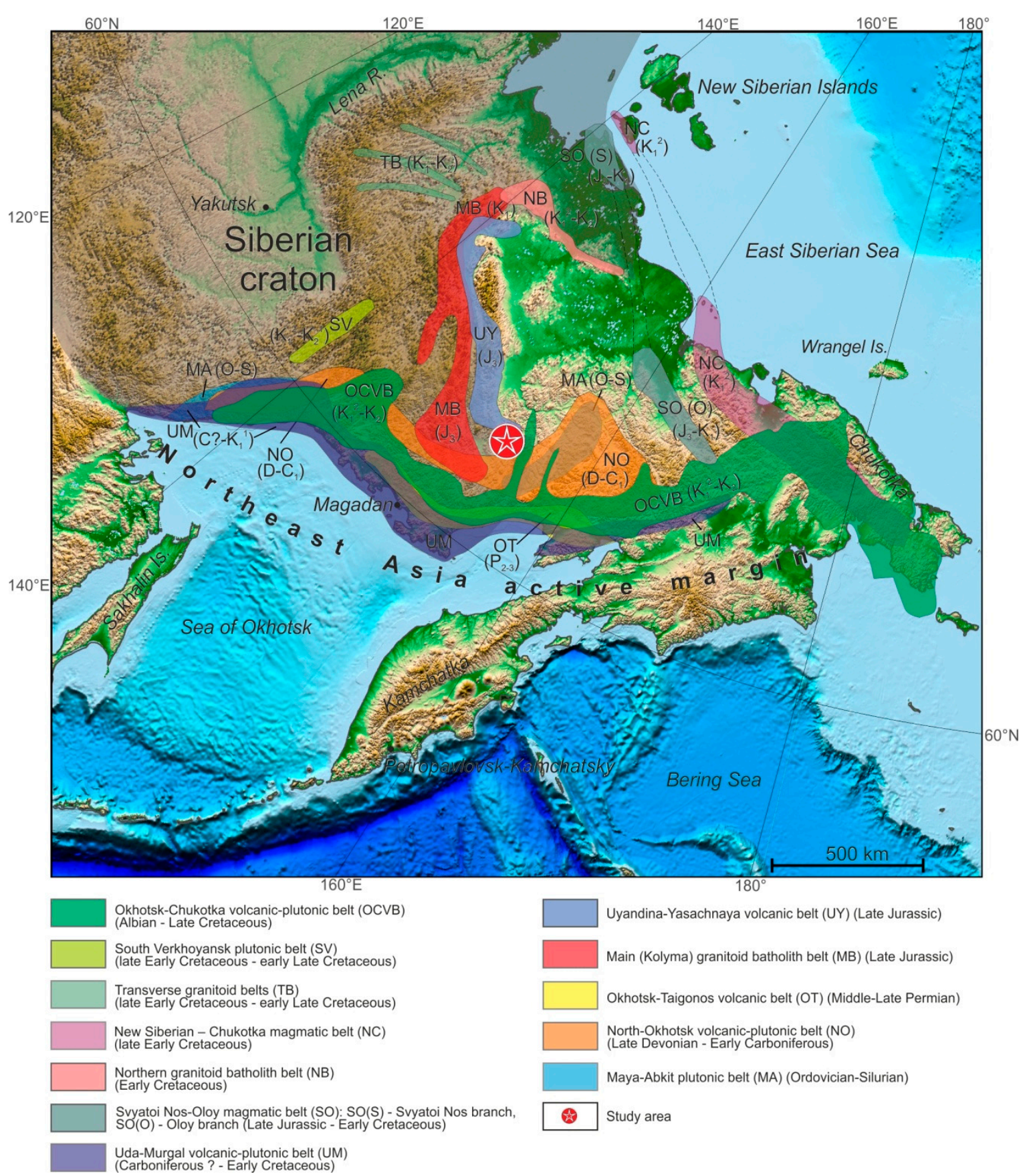

Figure 1. Schematic Map illustrating the locations of the Main Paleozoic-Mesozoic Magmatic belts of the north-east Asia active Margin. Modified after [1].

A number of coeval Late Mesozoic sedimentary basins of varying sizes formed across NE Asia in response to this tectonic and Magmatic activity, but their geological histories are poorly understood due to the lack of geological constraints on their tectonic settings, paleogeographic affinities, and sedimenatry provenance. Clastic sedimentation within these basins occurred synchronously with Magmatic activity across the north-east Asia active Margin; therefore, their sedimentary fill and provenance can be used to constrain the history of Magmatic activity within this region. 
Detrital zircon provenance studies have been an effective and widely-used approach for reconstructing linkages between sedimentary basins and their tectono-magmatic source regions, providing independent constraints on the affinity of rocks in provenance regions and their tectonic settings. Here we present the first detrital zircon U-Pb data from Mesozoic rocks in the Sugoi and Omsukchan (Balygychan-Sugoi) basins, located in the south-eastern part of the Verkhoyansk-Kolyma orogenic belt in north-east Asia in order to reconstruct the provenance and tectonic evolution of the this key part of NE Asia.

\section{Geological Setting}

\subsection{Kolyma-Omolon Superterrane}

The composite Kolyma-Omolon Superterrane (microcontinent), located in the eastern part of the Verkhoyansk-Kolyma orogen, comprises a collage of fault-bounded blocks (terranes) of various geodynamic origins [5,6,8-10,12]. In the vicinity of the study area, the tectonic basement units are Mainly associated with the Prikolyma, Omolon, and Omulevka terranes (Figure 2). The Prikolyma Terrane is composed of intensely deformed Paleoproterozoic to Carboniferous rocks, overlain by less deformed Permian and Mesozoic clastic and volcaniclastic rocks (e.g., [5,8,21-24]). The Omolon Terrane comprises Archean to Paleoproterozoic metamorphic basement (e.g., $[25,26])$, unconformably overlain by Mesoproterozoic to Ordovician clastic and carbonate rocks. The uppermost part of the succession of the Omolon Terrane comprises Devonian to early Mississippian arc-related volcanic rocks of the Kedon Formation (North-Okhotsk arc) and late Mississippian clastic rocks [5,8,27-30]. The Omulevka Terrane, in general, consists of Cambrian to Triassic clastic and carbonate rocks, but the Rassokha and Uvyazka blocks in the eastern part of the terrane contain Early Silurian arc-related felsic Magmatic rocks [31] and Middle Devonian trachyte plutons [32].

\subsection{Main Paleozoic-Mesozoic Magmatic Belts of the NE Asia Active Margin}

\subsubsection{Maya-Abkit Magmatic Belt}

Fragments of this Magmatic belt are represented by Early Paleozoic Magmatic and volcanic rocks. Late Ordovician arc-related granites exposed across the south-western Okhotsk Terrane with a zircon U-Pb crystallization ages of $445.7 \pm 1.5 \mathrm{Ma}, 447$ and $451 \mathrm{Ma}$ [33]. Early to Middle Silurian syenite and granite intrusions are associated with slab-window related asthenospheric upwelling across the Omolon-Taigonos area, with zircon U-Pb crystallization ages of 433-425 Ma [34]. In the South Verkhoyansk region, Ordovician Mafic dikes and sills with baddeleyite $\mathrm{U}-\mathrm{Pb}$ ages of 445-458 Ma have been reported [35-37], while Ordovician arc-related volcanic and volcaniclastic rocks occur in the Omulevka Terrane [38-40]. SHRIMP zircon U-Pb dating of small island arc-type granitic plutons within the Rassokha block of the Omulevka Terrane yielded a crystallization age of $440 \pm 2 \mathrm{Ma}$ [31] (Figure 1).

\subsubsection{North Okhotsk Magmatic Belt}

This belt of Devonian-Early Carboniferous volcanic rocks was recognized by Parfenov et al. [6] and Badarch et al. [41] (Figure 1). Devonian-Early Carboniferous subductionrelated effusive rocks of the Kedon Complex, including trachybasalts, trachyandesites, rhyolites, trachyrhyolites, tuffs and volcaniclastic rocks with thicknesses from 1250 to 4350 $\mathrm{m}$, have been documented in the Omolon Terrane and southern part of the Prikolyma Terrane e.g., [11,28]. The ages of these rocks were established on the basis of fossil fauna and zircon $\mathrm{U}-\mathrm{Pb}$ ages. Rhyolites yielded $\mathrm{U}-\mathrm{Pb}$ zircon ages of 402 and $387 \mathrm{Ma}$ [27], while felsic intrusions are 335 and $338 \mathrm{Ma}$ in age [29,30].

Upper Devonian (Frasnian to Famennian) volcanic and sedimentary rocks are exposed in the south-western and central parts of the Okhotsk Terrane, comprising 1300 meters of rhyolitic to andesitic lavas, tuffs, and volcaniclastic rocks [42-45]. Arc-related granitoid plutons gave zircon U-Pb ages of $375 \mathrm{Ma}$ [45]. 


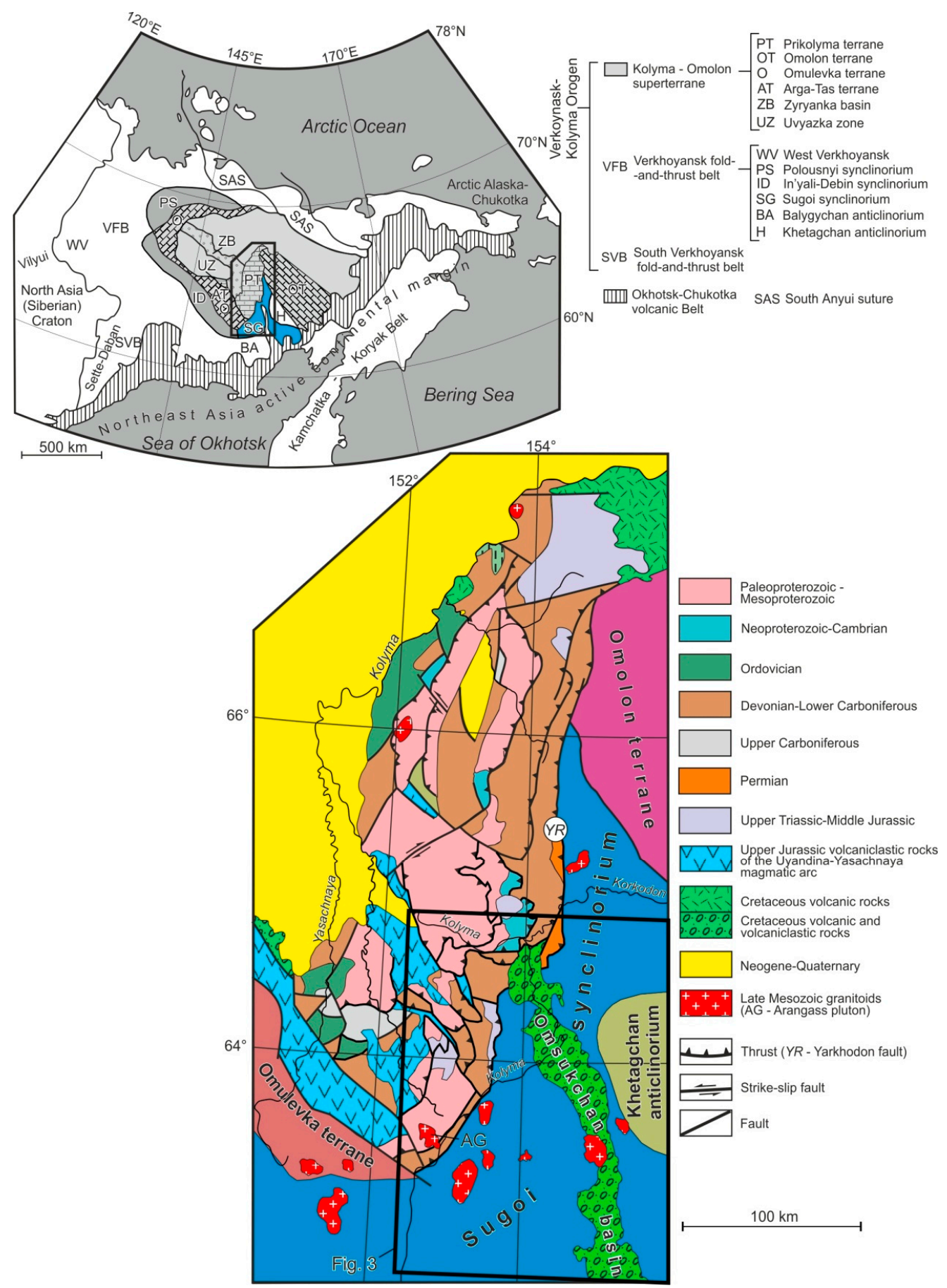

Figure 2. Main geological units of the Prikolyma Terrane and Sugoi synclinorium (modified [21]). Inset Map shows location of the region and Main tectonic units.

\subsubsection{Main (Kolyma) Batholith Belt}

This SE-NW-oriented Magmatic belt extends for more than $1000 \mathrm{~km}$ along the axial part of the Verkhoyansk-Kolyma orogenic belt and orthogonal to the Sea of Okhotsk coast and to the strike of older subduction-related Magmatic belts (Figure 1) (e.g., [2,46-48]) It is formed by a few hundred biotite-hornblende granodiorite and granite plutons of varying sizes, along with numerous felsic dikes. Both S- and I-type granites are present (e.g., [1,48]), coeval to the Uyandina-Yasachnaya volcanic rocks exposed in the north-east of the Main (Kolyma) belt. The geodynamic setting for the Main (Kolyma) belt remains a Matter of debate. Some studies have proposed that it was formed in response to the 
collision of the Kolyma-Omolon Superterrane with Siberia (e.g., [2,6-8,49,50]), while others claimed that it represents the product of subduction-related Magmatism (e.g., [1,48,51,52]). $\mathrm{U}-\mathrm{Pb}$ crystallization ages of the plutons vary from 165 to $144 \mathrm{Ma}$, with a predominant mode at about $150 \mathrm{Ma}[1,48,53]$. The plutons exhibit a younging trend to the north-west, which has been attributed to oblique subduction followed by transpressive collision of the Kolyma-Omolon Superterrane with the Siberian Craton Margin [52]. Numerous biotite ${ }^{40} \mathrm{Ar} /{ }^{39} \mathrm{Ar}$ ages between $143-138 \mathrm{Ma}$ [50] reflect the timing of cooling in response to tectonic unroofing and exhumation during collision between the Superterrane and the Craton. In the north-west, the Main belt joins the Northern belt (see below), thereby forming an arcuate composite Magmatic belt, referred to as the Kolyma loop.

\subsubsection{Northern Batholith Belt}

This WSW-ENE-oriented Magmatic belt stretches for over $650 \mathrm{~km}$ at an acute angle to the north-western termination of the Main (Kolyma) belt to form the northern flank of the composite Kolyma loop (Figure 1) (e.g., [3,5,50]). Most plutons in this belt consist of diorites to monzonites with minor granites and granodiorites - all classified as I-type arc granitoids. These intrusions are interpreted to have been emplaced in a suprasubduction setting (e.g., [5,50]). Zircon U-Pb ages from Major plutons range from 140 to $129 \mathrm{Ma}$ [1], younging in an eastward direction, while ${ }^{40} \mathrm{Ar} /{ }^{39} \mathrm{Ar}$ ages of the plutons vary from 144 to $123 \mathrm{Ma}[50]$.

\subsubsection{Uyandina-Yasachnaya Magmatic Belt}

This belt represents a $150 \mathrm{~km}$-wide Magmatic arc, paralleling the Main Kolyma batholitic belt on its NE flanks and stretching for nearly $1000 \mathrm{~km}$ across the axial portion of the Verkhoyansk-Kolyma orogenic belt (Omulevka Terrane and adjacent areas of the In'yali-Debin and Polousnyi synclinoria), as far as the southern Prikolyma Terrane (Figure 1). The arc consists of Oxfordian-Tithonian volcanic and volcaniclastic rocks, varying in thickness from a few hundred meters to a Maximum of $3500 \mathrm{~m}$. The volcanic rocks are dominated by andesite, basalt, andesite-basalt, and more acidic varieties, including rhyolite. Tuffs of various types and compositions are common. The Uyandina-Yasachnaya Magmatic arc has been interpreted as being related to subduction associated with closure of the Oymyakon Ocean, although the polarity of the subduction zone remains debated (e.g., [1-3,5,8,51]). The ages of the volcaniclastic rocks, constrained by fossils and zircon U-Pb dated at 153-150 Ma [1,12,50,52], are nearly coeval with those of the Main (Kolyma) belt granitoids described above.

\subsubsection{Uda-Murgal Magmatic Belt}

This Magmatic belt extends for over $2000 \mathrm{~km}$ along the Sea of Okhotsk coast from Uda Bay to the northern extremity of Kamchatka, but is generally less than $100 \mathrm{~km}$ wide (Figure 1). It has an arc affinity and is composed of volcanic and volcaniclastic rocks including andesites, basaltic andesites, rhyolites, dacites, basalts, and tuffs, with thicknesses ranging from 3000 to $7000 \mathrm{~m}$ (e.g., $[2,19,54,55])$. There are contrasting interpretations and models for the age of the Uda-Murgal Magmatic belt. According to Parfenov [2], the Uda-Murgal volcanic arc existed from the Permian to the Early Cretaceous on the basis of volcanic rocks of Late Permian-Jurassic age (as indicated by fossils) described from the Taigonos Peninsula, Late Triassic to Late Jurassic age from the Koni Peninsula, and Early to Late Jurassic age from the Pyagin Peninsula. Parfenov [2] also recognized the Triassicpre-Albian Uda and Koni-Murgal continental Magmatic arcs along the north-western and northern Margins of the Sea of Okhotsk. However, within the Uda-Murgal Magmatic belt, Sokolov [56] documented the older Late Paleozoic-Early Mesozoic Koni-Taigonos Magmatic arc that is superimposed by the younger Late Jurassic-Early Cretaceous Uda-Murgal arc. The Kobyume graben, in the back-arc region of the Uda-Murgal arc, contains up to $800 \mathrm{~m}$ of basalt, basaltic andesite, and tuffs [57], which Prokopiev et al. [58] suggested to have formed during extension in the back-arc region of the Uda-Murgal arc. Biakov 
et al. [59-61] reported calc-alkaline volcanics of the late Middle-Late Permian age in the east of the Okhotsk Terrane and ascribed them to the Okhotsk-Taigonos volcanic arc, although they could have alternatively been assigned to the Uda-Murgal Magmatic belt. Mesozoic diorite and granodiorite plutons and volcanic rocks have yielded zircon U-Pb ages of 160-100 Ma (e.g., [1,62] and references therein). Late Paleozoic-Early Mesozoic volcanics of the Uda-Murgal Magmatic belt Mainly comprise basalts and andesites $[2,54,55]$ containing very few zircons, thus accounting for the lack of Late Paleozoic-Early Mesozoic detrital zircon U-Pb age modes in sedimentary samples [1]. Along the south-eastern Margin of the belt in the Uda Gulf of the Sea of Okhotsk, 176-178 Ma basaltic andesites and andesites $\left({ }^{40} \mathrm{Ar} /{ }^{39} \mathrm{Ar}[63]\right)$ and $181 \pm 2 \mathrm{Ma}$ granites (zircon U-Pb [64]) have been reported.

\subsubsection{Svyatoi Nos-Oloy Magmatic Belt}

This Magmatic belt extends for more than $1200 \mathrm{~km}$ along the coasts of the Laptev and East Siberian Seas in the Svyatoi Nos Cape area, along the northern Margin of the Verkhoyansk-Kolyma orogenic belt (Figure 1). The belt can be divided into two branches: the Svyatoi Nos and Oloy. The Svyatoi Nos branch (e.g., [2,5,9]) is composed of Late Jurassic-Early Cretaceous andesites, tuffs, and greywackes with thicknesses exceeding 400 $\mathrm{m}$ (e.g., [5,65]). They were intruded by minor granitoid plutons and dikes with U-Pb ages of 114-112 Ma and 119-111 Ma, respectively [65]. A bulk of this branch has been buried beneath younger Cenozoic sedimentary strata along the Margin of the Laptev Sea.

The eastern portion of the belt-the Oloy branch-is located between the Kolyma, Omolon, and Bolshoy Anyui rivers, south of the South Anyui suture $[5,8,9,14,39]$. It consists of Mafic, intermediate, and acidic volcanic rocks, associated volcaniclastic rocks, and small plutons. An Early Cretaceous age of the volcaniclastic rocks was constrained by fossils and corroborated by zircon U-Pb ages ranging from 150 to $137 \mathrm{Ma}$ [1]. Dacites yielded a zircon $\mathrm{U}-\mathrm{Pb}$ crystallization age of $174 \mathrm{Ma}$, while other granodiorite-diorite plutons were dated at 142-139 Ma [66].

The composite Svyatoi Nos-Oloy Magmatic belt was formed during closure of the South Anyui Ocean, resulting in the collision of the Arctic Alaska-Chukotka Superterrane with the Siberian Margin [5,65]. The Late Jurassic-Early Cretaceous volcanic and volcaniclastic rocks are consistent with the characteristics of a continental arc, while the Aptian-Albian granitoids in the Svyatoi Nos Cape area and Berriasian-Valanginian granodiorites of the Oloy branch reflect either the final Magmatic phase of the Magmatic arc or the incipient continental collision and formation of the Novosibirsk-Chukotka orogeny (e.g., $[16,18])$.

\subsubsection{New Siberian-Chukotka Magmatic Belt}

This Magmatic belt extends for more than $2000 \mathrm{~km}$ from the south-western part of the New Siberian Islands archipelago to the lower reaches of the Kolyma River and Chukotka (Figure 1). This Magmatic belt sits outboard from the Svyatoi Nos-Oloy Magmatic belt and was emplaced within the Arctic Alaska-Chukotka Superterrane. While granite plutons of the New Siberian Islands yielded U-Pb ages as old as 121-144 Ma [67] and ${ }^{40} \mathrm{Ar} /{ }^{39} \mathrm{Ar}$ cooling ages at 113-105 Ma [49], zircon U-Pb ages obtained from granitoid plutons in Chukotka gave systematically younger ages ranging from 121 to $100 \mathrm{Ma}$ [1,62,68-77].

\subsubsection{South Verkhoyansk Magmatic Belt}

This N-S-oriented Magmatic belt attains a length of $400 \mathrm{~km}$ in the central portion of the Verkhoyansk orogenic belt in the back-arc region of the Uda-Murgal and OkhotskChukotka arcs (Figure 1). The granitoids it contains were emplaced during two Major pulses of subduction-related Magmatism and deformation in the region at 125-120 Ma (Early Cretaceous) and 95-90 Ma (early Late Cretaceous) [44,78,79]. 


\subsubsection{Okhotsk-Chukotka Magmatic Belt}

The Okhotsk-Chukotka Magmatic belt is the largest in north-east Asia, extending over $3000 \mathrm{~km}$ from the north-western corner of the Sea of Okhotsk coast as far as the eastern termination of Chukotka, with a width of 100 to $400 \mathrm{~km}$ (Figure 1). This voluminous volcanic arc is composed of a thick succession of volcanic and volcaniclastic rocks with a Maximum thickness of up to several kilometers. The belt is interpreted as an Andean-type continental Magmatic arc [1,2,4,77,80,81]. The Aptian-Late Cretaceous age of the volcanic and volcanoclastic rocks were determined by fossil flora, while zircon $\mathrm{U}-\mathrm{Pb}$ and mica ${ }^{40} \mathrm{Ar} /{ }^{39} \mathrm{Ar}$ ages from the volcanic and plutonic rocks clustered between 106-76 Ma [1,62,73,74,76,77,81-86].

\subsection{Sugoi Synclinorium and Omsukchan Basin}

The Sugoi synclinorium is located within the south-eastern part of the VerkhoyanskKolyma orogenic belt and is separated by Major faults from the Omulevka, Prikolyma, and Omolon terranes of the Kolyma-Omolon Superterrane (microcontinent). To the east of the Sugoi synclinorium (in present-day coordinates), the Khetagchan anticlinorium comprises Triassic clastic deposits. Similarly, the Balygychan anticlinorium to the south also Mainly contains Triassic clastic deposits and is separated from the Sugoi synclinorium by a series of faults. A Major sinistral strike-slip fault separates the Sugoi from the In'yaliDebin synclinorium to the south-west, which exposes a thick succession of Triassic-Jurassic strata [87-89] (Figures 2 and 3).

The Sugoi synclinorium comprises mostly Jurassic clastic strata attaining a total thickness of up to $2700 \mathrm{~m}$ [87] (Figure 4), with small outcrops of Upper Triassic rocks in the cores of anticlines. The thickness of Jurassic rocks is likely an overestimation due to superimposed shortening. The Marat Formation (up to $800 \mathrm{~m}$, Lower Jurassic) comprises siltstone and mudstone with interbeds of limestone. The Memechen Formation (600-1000 m) and the Oktyabrin Formation (up to $700 \mathrm{~m}$, Middle Jurassic) comprise sandstone, siltstone, and mudstone. The Kuchukan Formation (150-200 m, Upper Jurassic) is represented by intercalating sandstone, siltstone, and mudstone [87] (Figure 4). The age of the formations is constrained by fossil findings [87].

The Sugoi synclinorium has been considered the easternmost continuation of the In'yali-Debin synclinorium [87]. The paleogeographic association and tectonic setting of these Jurassic and Triassic clastic strata is debated. The In'yali-Debin synclinorium has been considered as part of the Polousnyi-Debin Terrane of the Kolyma-Omolon Superterrane [5,6,8,9], with Upper Triassic-Jurassic clastics deposited along the southwestern Margin of the Kolyma-Omolon Superterrane prior to its accretion to Siberia in the Late Mesozoic. However, detrital zircon U-Pb age data from Triassic-Jurassic strata in the In'yali-Debin synclinorium were used to suggest that these strata were deposited along the eastern Verkhoyansk passive Margin of Siberia [90]. Alternatively, Parfenov and Nokleberg $[8,9,89]$ proposed that the Mesozoic rocks of the Sugoi synclinorium were deposited within the Marginal sea associated with the Kolyma-Omolon Superterrane or in the back-arc basin of the Uda-Murgal arc [87].

The Omsukchan basin [89] (also known as the Balygychan-Sugoi basin [87]) stretches in a meridional direction for over $300 \mathrm{~km}$ from the Sea of Okhotsk to the middle course of the Kolyma River, with a Maximum width of the exposure belt of $50 \mathrm{~km}$ (Figures 2 and 3). The basin comprises a Massive section of continental Cretaceous volcanic and volcaniclastic rocks, reaching thicknesses of 5300 to $9500 \mathrm{~m}$ [87] (Figure 5), with an angular unconformity separating Cretaceous rocks of the Omsukchan basin from intensely deformed Triassic and Jurassic rocks of the Sugoi synclinorium [87]. Cretaceous rocks are also deformed with local cleavage development. However, structural trends and orientation of the Omsukchan basin are roughly orthogonal to the axial traces of the Sugoi synclinorium (Figures 2 and 3). The Hauterivian-Barremian rocks are rhyolite, tuffs, tuffaceous sandstone, and shale. The oldest Aptian deposits of the Omsukchan basin comprise rhyolite, ignimbrite, and shale in the lower part and siltstone, andesite, and basalt in the middle part, grading 
to sandstone and siltstone in the upper part of the basal succession. The lower Albian rocks are predominantly clastic with intercalated andesitic tuffs and basalt flows. Upper Albian to lower Cenomanian deposits comprise andesite, tuffs, tuffaceous sandstone, and conglomerate, which are overlain by upper Cenomanian tuffs, rhyolite, dacite, and sandstone. The lower part of the Turonian-Campanian succession consists of tuffs, rhyolite, dacite, and sandstone, while the upper-most portion is Mainly sandy in composition (Figure 5). The ages of the Omsukchan basin deposits are Mainly based on fossil flora [4] and rare $\mathrm{K}-\mathrm{Ar}, \mathrm{Rb}-\mathrm{Sr}$ and $\mathrm{U}-\mathrm{Pb}$ dates [87]. Zircon $\mathrm{U}-\mathrm{Pb}$ dating yielded ages of 132-134 Ma for rhyolites of the Askold Formation, while dacites and rhyolites of the Shorokh Formation gave ages of 82-86 Ma [91] (Figure 5). The Omsukchan basin sedimentary strata were intruded by Late Cretaceous felsic and Mafic plutons and dikes (Figures 2, 3 and 5). The Cretaceous Omsukchan basin is overlain by Paleogene continental deposits above an angular unconformity.

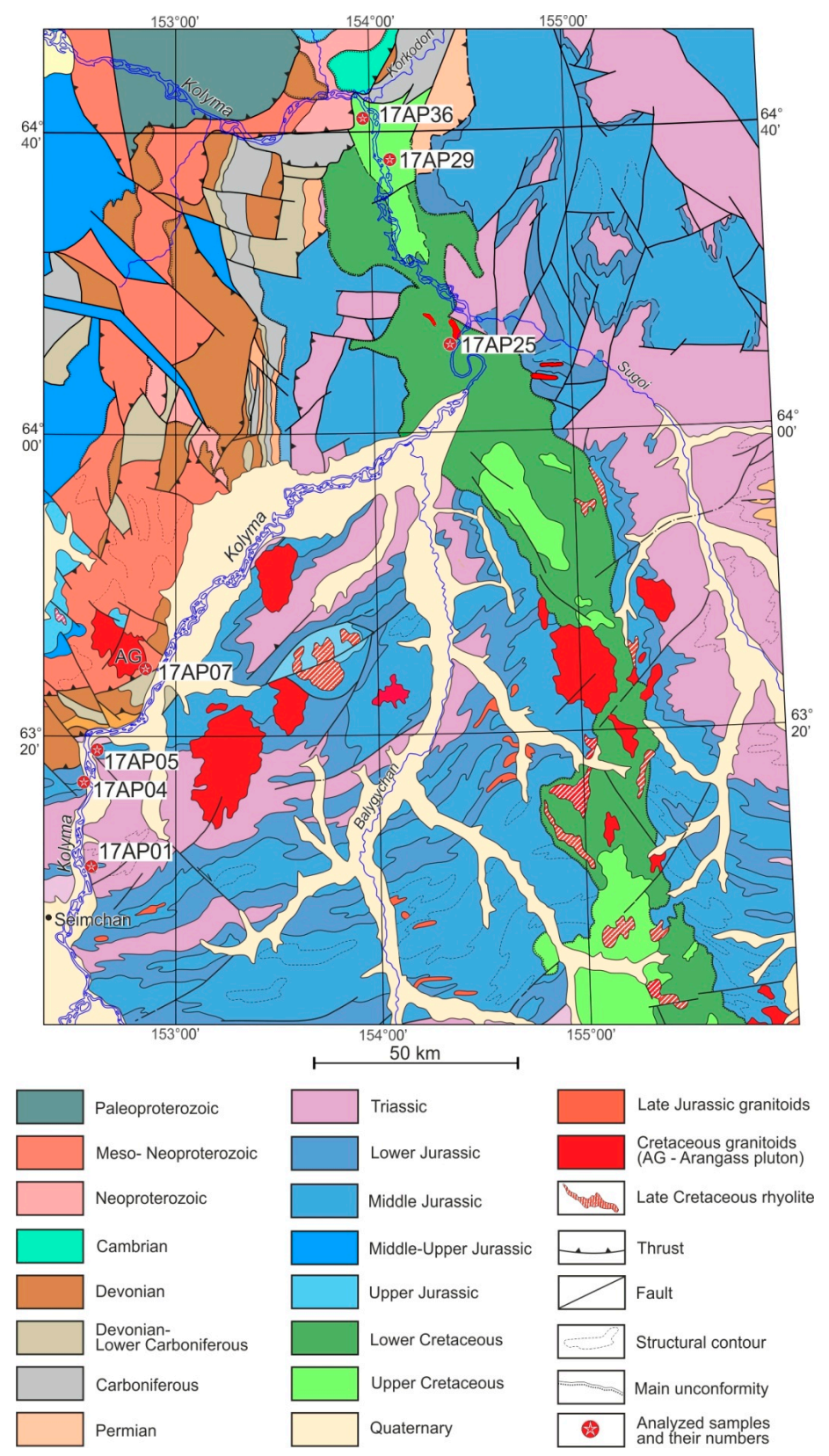

Figure 3. Geological Map of the boundary zone between the southern Prikolyma Terrane and northern Sugoi synclinorium (modified $[87,88]$ ). See Figure 2 for location. 


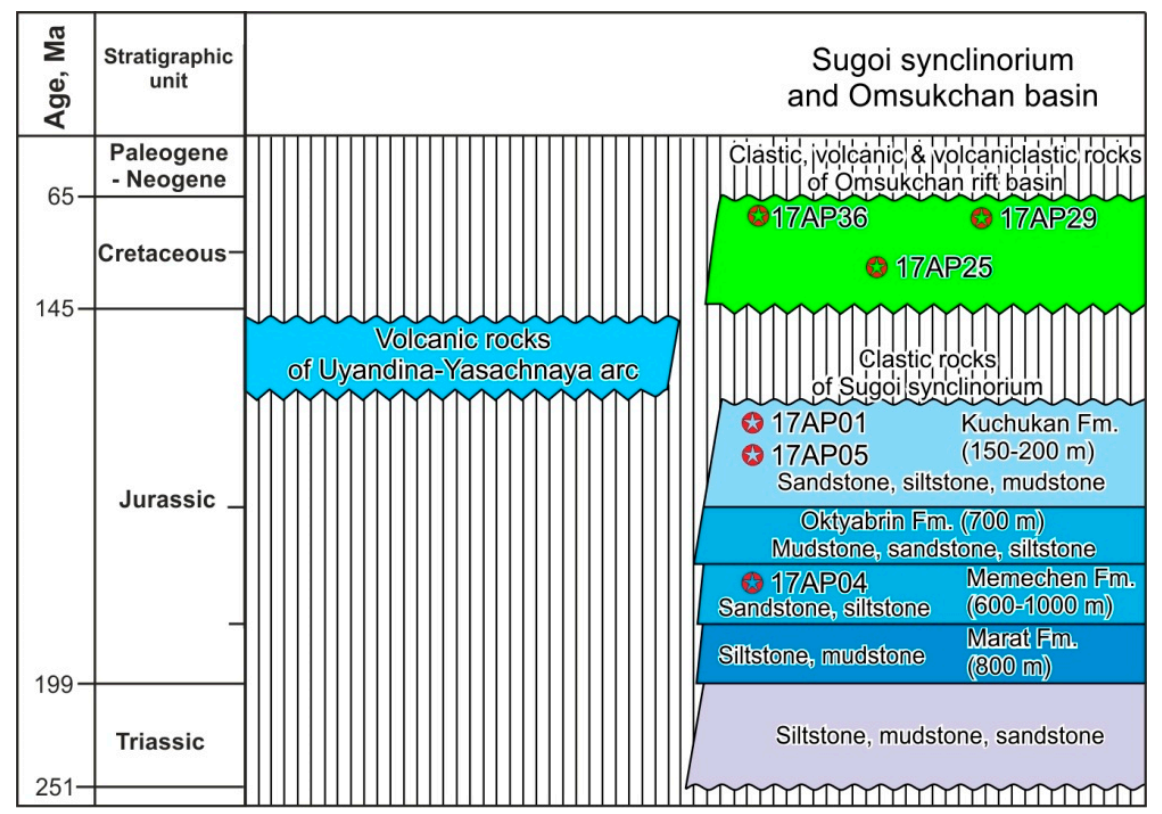

Figure 4. Generalized stratigraphic column of the Sugoi synclinorium and Omsukchan basin with position of dated samples.

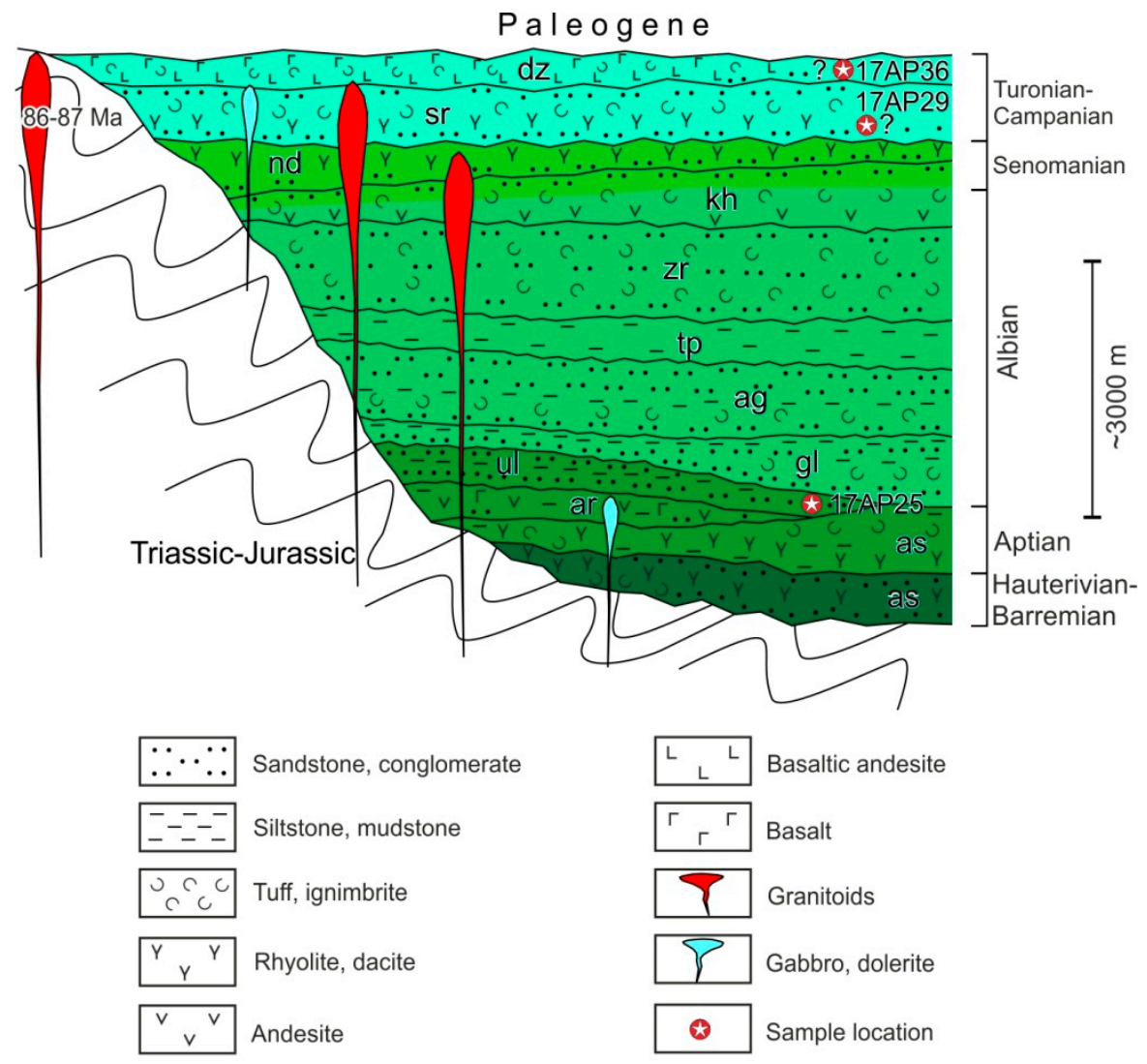

Formations: as - Askold, ar - Arylakh, ul - Ulik, gl - Galimov, ag - Aigur, tp - Toptan, zr - Zorin, kh - Kakhovka, nd - Nadezhda, sr - Shorokh, dz - Dzhhagyn

Figure 5. Schematic geological section of the Omsukchan basin (data from [87]). The stratigraphic age of 17AP29 and 17AP36 are shown based on their Maximum depositional ages.

The origin of the Omsukchan basin is still debated. Belyi [4] considered the Omsukchan basin as an orthogonal branch of the Okhotsk-Chukotka volcanic belt. However, only its upper parts (late Albian-Campanian) are coeval with the Okhotsk-Chukotka 
volcanic belt, while the Aptian-lower Albian succession is contemporaneous with the Uda-Murgal Magmatic belt [1,87]. In contrast, Parfenov [3], Kuznetsov, and Livach [92] interpreted the Omsukchan basin as a piggy-back basin with the Verkhoyansk-Kolyma orogenic belt. However, most recent studies have considered the basin as rift-related [93-98].

\section{Materials and Methods}

In order to elucidate the provenance and tectonic setting of the strata of the Sugoi synclinorium and Omsukchan basin, six clastic rock samples were collected from JurassicCretaceous strata of the Sugoi synclinorium and Omsukchan basin (Figures 5 and 6), as well as one sample from the cross-cutting Arangass granite pluton along the Kolyma River (Figure 3, Table 1).
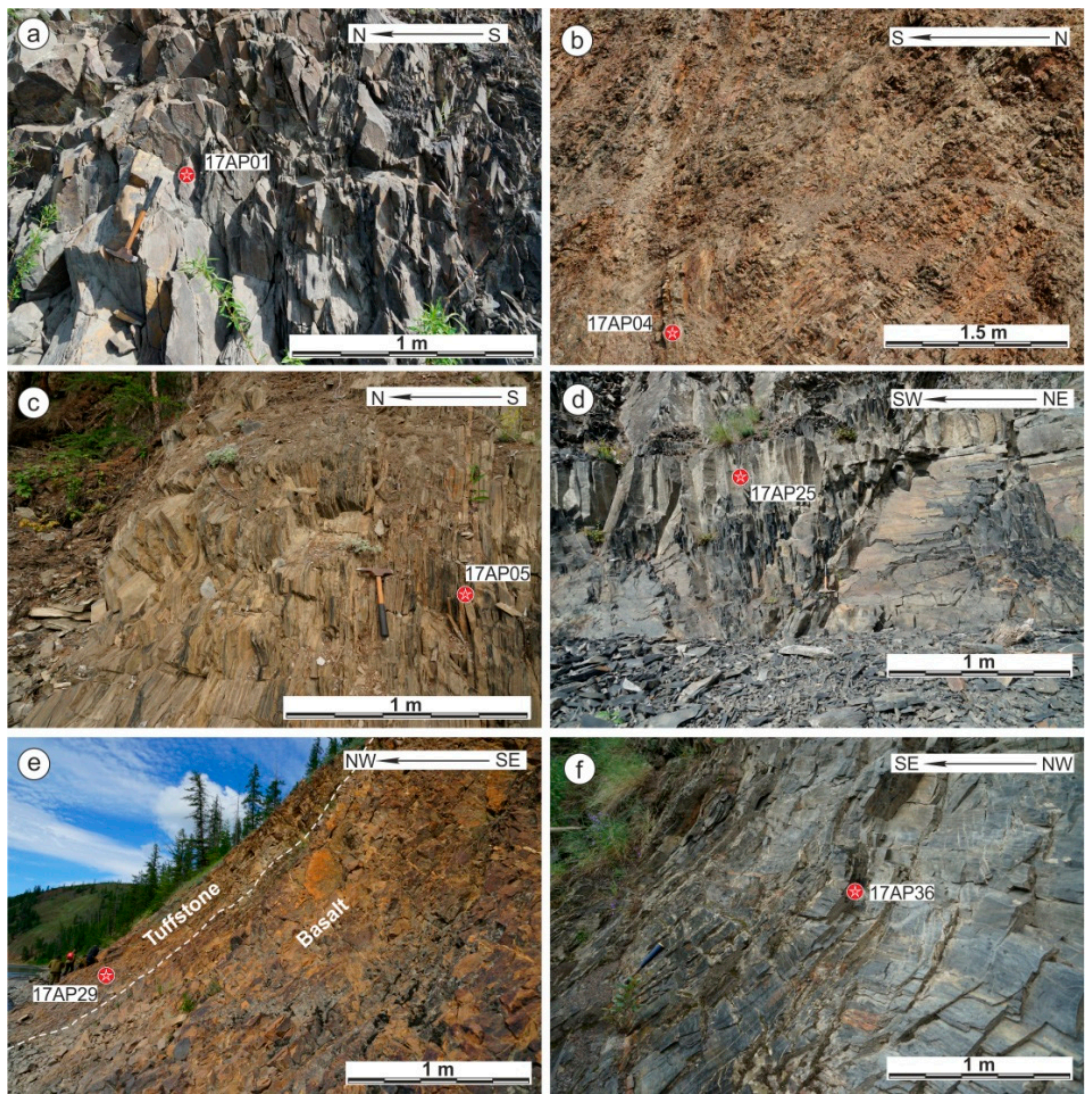

Figure 6. (a-f) Photos of the outcrops of the studied rocks. The star shows the location of the sample.

Table 1. Summary of locations of analyzed samples.

\begin{tabular}{cccc}
\hline Sample Number & Latitude & Longitude & Stratigraphic Age; Formation \\
\hline 17AP01 & $\mathrm{N} 63^{\circ} 02^{\prime} 52.1^{\prime \prime}$ & $\mathrm{E} 152^{\circ} 33^{\prime} 05.1^{\prime \prime}$ & Upper Jurassic; Kuchukan Formation [87] \\
17AP04 & $\mathrm{N} 63^{\circ} 14^{\prime} 27.5^{\prime \prime}$ & $\mathrm{E} 152^{\circ} 34^{\prime} 15.3^{\prime \prime}$ & Middle Jurassic; Memechen Formation [87] \\
17AP05 & $\mathrm{N} 63^{\circ} 19^{\prime} 03.2^{\prime \prime}$ & $\mathrm{E} 152^{\circ} 34^{\prime} 34.0^{\prime \prime}$ & Upper Jurassic; Kuchukan Formation [87] \\
17AP25 & $\mathrm{N} 64^{\circ} 13^{\prime} 02.7^{\prime \prime}$ & $\mathrm{E} 154^{\circ} 27^{\prime} 16.1^{\prime \prime}$ & Aptian [87]; Ulik Formation \\
$17 \mathrm{AP} 29$ & $\mathrm{~N} 64^{\circ} 37^{\prime} 42.1^{\prime \prime}$ & $\mathrm{E} 154^{\circ} 01^{\prime} 19.5^{\prime \prime}$ & Younger than Coniacian-this study; Late Carboniferous-Early \\
& & Permian; Monkhaidyn Formation [87] \\
17AP36 & $\mathrm{N} 64^{\circ} 42^{\prime} 37.6^{\prime \prime}$ & $\mathrm{E} 153^{\circ} 58^{\prime} 51.7^{\prime \prime}$. & Younger than Campanian-this study; Late Carboniferous-Early \\
$17 \mathrm{AP} 07$ & $\mathrm{~N} 63^{\circ} 28^{\prime} 07.5^{\prime \prime}$ & $\mathrm{E} 152^{\circ} 52^{\prime} 53.8^{\prime \prime}$ & Arangass pluton. Cretaceous (86-87 Ma-this study) Coniacian \\
\hline
\end{tabular}

All samples were analyzed at the UTChron geochronology facility at the Department of Geological Sciences at the University of Texas, Austin, TX, USA. Samples underwent 
conventional heavy mineral separation and were grain mounted (no polishing) on oneinch round epoxy pucks with double-sided tape. All grains were depth-profiled using a Photon Machines Analyte G2 ATLex 300si ArF 193 nm Excimer Laser, equipped with a Helix two-volume ablation cell using procedures of Marsh and Stockli [99]. The ablated aerosols were transported using He carrier gas to a Thermo Fisher Element2 single collector, Magnetic sector-ICP-MS for isotopic determinations. GJ1 was used as primary zircon standard $(206 \mathrm{~Pb} / 238 \mathrm{U} 601.7 \pm 1.3 \mathrm{Ma}, 207 \mathrm{~Pb} / 206 \mathrm{~Pb} 607 \pm 4 \mathrm{Ma}$; [100]) and interspersed every $4-5$ unknown analyses for elemental and depth-dependent fractionation. Plešovice $(337.1 \pm 0.4 \mathrm{Ma}$, [101]) was used as a secondary standard to monitor data quality. No common $\mathrm{Pb}$ correction was applied due to $\mathrm{Hg}$ interference. Data reduction was performed using the IgorPro [102] based Iolite 3.4 software with Visual Age data reduction scheme [103]. All uncertainties are quoted at $2 \sigma$. For data interpretations, $206 \mathrm{~Pb} / 238 \mathrm{U}$ ages were used for zircons $<1 \mathrm{Ga}$, while $207 \mathrm{~Pb} / 206 \mathrm{~Pb}$ ages were used for older zircons. Detrital and Magmatic zircon $\mathrm{U}-\mathrm{Pb}$ analytical results tables are provided in Supplementary Materials. Histograms were constructed using the detzrcr software (version 1.0, University of Oslo, Oslo, Norway) [104].

\section{Results \\ 4.1. Petrography of Studied Rocks \\ Sample 17AP01}

This is a fine- to medium-grained, poorly sorted arkosic arenite (Figure 7). Quartz contribute $25-30 \%$ of total grain population. Grains are angular to sub-angular. Feldspar grains are angular to sub-angular and up to $40-50 \%$. Lithic grains comprise $20-15 \%$ and are Mainly volcanic in composition. Cleavage is observed.
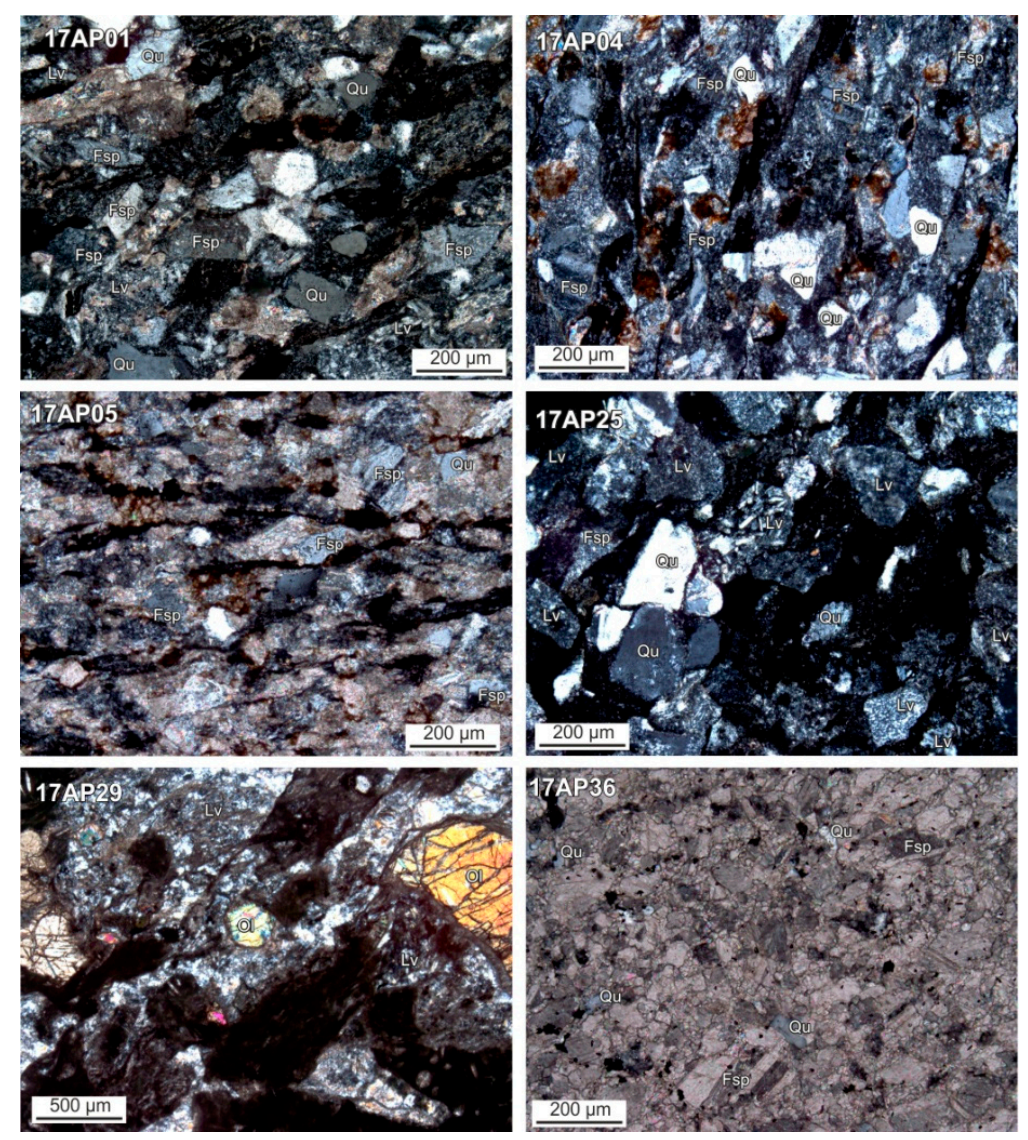

Figure 7. Petrography of the studied rocks. Qu-quartz, Fsp-feldspar, Lv-lithic volcanic grains, Ol-olivine. 


\section{Sample 17AP04}

This is a fine-grained silty arkosic arenite (Figure 7). Quartz grains are angular to sub-angular and contribute $50-60 \%$ of total grain population. Feldspar grains are angular to sub-angular up to $40-50 \%$. Lithic grains are rare. Cleavage is observed.

\section{Sample 17AP05}

This is a fine-grained arkosic arenite with secondary carbonate cement (Figure 7). Quartz grains are angular to sub-angular and contribute $50-60 \%$ of total grain population. Feldspar grains are angular to sub-angular up to $40-50 \%$. Lithic grains are rare. Cleavage is observed.

Sample 17AP25

This is a medium- to coarse-grained lithic arenite with the Majority of lithic grains (30-35\%) being volcanic in composition (Figure 7). Quartz and feldspar grains are angular to sub-angular and contribute $40-45 \%$ and $20-30 \%$, respectively.

\section{Sample 17AP29}

This is a medium- to coarse-grained tuffstone (Figure 7). Clastic grains are Mainly lithic volcanic grains and olivine.

Sample 17AP36

This is a silty fine-grained arkosic arenite. Due to the widespread carbonatization and dissolution, the quantity of original clastic grains is difficult to calculate.

Sample 17AP07

This is an alkaline granite porphyry, which contains potassium feldspar (45-66\%), quartz (20-15\%), albite (3-25\%), hornblende, riebeckite, aegirine, and biotite (20\%).

\section{2. $U-P b$ Dating of Detrital Zircons}

A sample 17AP04 was collected from fine-grained silty arkosic arenite of the Middle Jurassic Memechen Formation (Figures 3, 4, 6 and 7, Table 1). The zircon age distribution is characterized by a subsidiary component of Precambrian zircons $(28 \%)$ that form a minor peak at $1860 \mathrm{Ma}$ (Figure 8). The Paleozoic grains (16\%) group around 380-430 Ma. The youngest zircons form a dominant age peak at $170 \mathrm{Ma}$ (56\% of the dated grains) (Figure 9).

Samples 17AP01 and 17AP05 were collected from Upper Jurassic (Kuchukan Formation) fine- to medium-grained poorly sorted arkosic arenite and fine-grained arkosic arenite, respectively (Figures 3, 4, 6 and 7, Table 1). Precambrian zircon Make up a subsidiary portion (26\%) of all analyses that yielded U-Pb ages from 1740 to $2000 \mathrm{Ma}$ (Figure 8). Only $15 \%$ of zircons are of Paleozoic age, forming two minor peaks at 320 and 380-430 Ma. A significant number of detrital zircons $(\sim 60 \%)$ yielded Jurassic ages, with a distinct peak at $170 \mathrm{Ma}$ and subordinate peak at $186 \mathrm{Ma}$ (Figure 9).

Sample 17AP25 was collected from an Aptian medium- to coarse-grained lithic arenite of the Ulik Formation (Figure 5, Table 1). While Precambrian zircons (8\%) do not represent a prominent peak (Figure 8 ) and Paleozoic grains (15\%) only form minor peaks in the age range 310-425 Ma, Mesozoic zircons represent the bulk (77\%) of the total population, with Major peaks at 144 and $187 \mathrm{Ma}$ (Figure 9).

Two samples (17AP29 and 17AP36) were analyzed from the Monkhaidyn Formation, previously considered to be Late Carboniferous-Early Permian in age [105] (Figures 2 and 3, Table 1) on the basis of unsubstantiated fossil evidence. Precambrian zircons (16\%) form two subsidiary age peaks at 1860-1890 Ma and 1950-2050 Ma (Figure 8), while Paleozoic zircons constitute $46 \%$ and $20 \%$ of the dated population in sample 17AP29 and 17AP36, respectively. Detrital ages of Paleozoic zircons from sample 17AP29 form two peaks at 309 and 395-465 Ma, while, in sample 17AP36, three minor peaks exist at 260-299, 381, and 430 Ma. Mesozoic grains Make up 39\% and $72 \%$ of the dated detrtial zircons in samples 17AP29 and 17AP36, respectively. The youngest zircons from both samples are Late Jurassic and Late Cretaceous in age and fall into two Major peaks at 155-158 Ma and 88-90 Ma (Figure 9). 

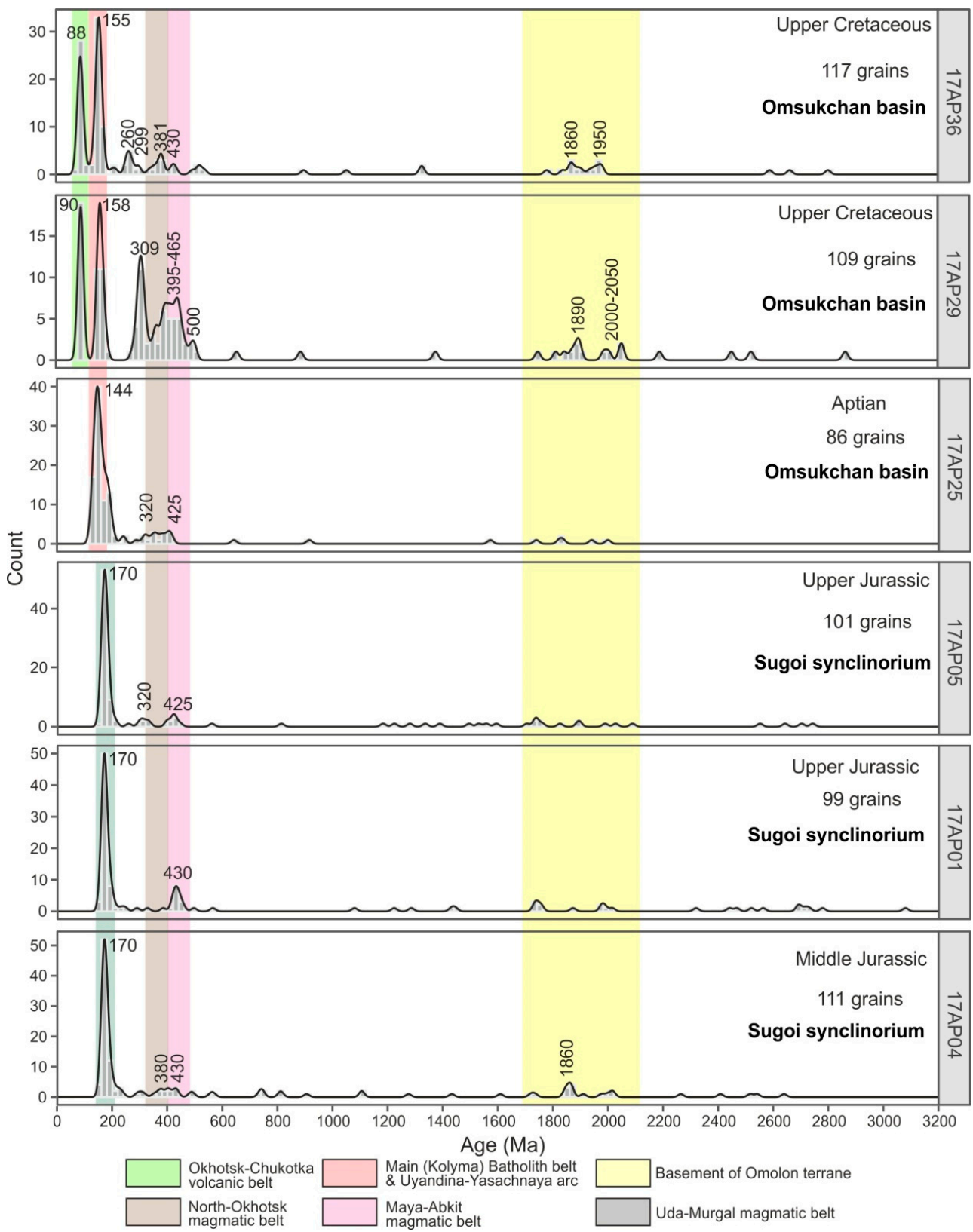

Figure 8. Kernel Density Estimation (KDE) plot showing all U-Pb detrital zircon data from the Middle-Upper Jurassic and Cretaceous samples analyzed in this work. The Main sources of detrital zircons are shown in color.

Sixteen zircons from the alkaline granite porphyry of the Arangass pluton (sample 17AP07) (Figures 2 and 3, Table 1, Table S1) yielded a weighted average zircon ${ }^{206} \mathrm{~Pb} /{ }^{238} \mathrm{U}$ age of $86.9 \pm 0.79 \mathrm{Ma}$ (Figure 10A), while seven concordant zircon grains yielded a U-Pb concordia age of $86.7 \pm 0.8 \mathrm{Ma}$ (Coniacian) (Figure 10B). 


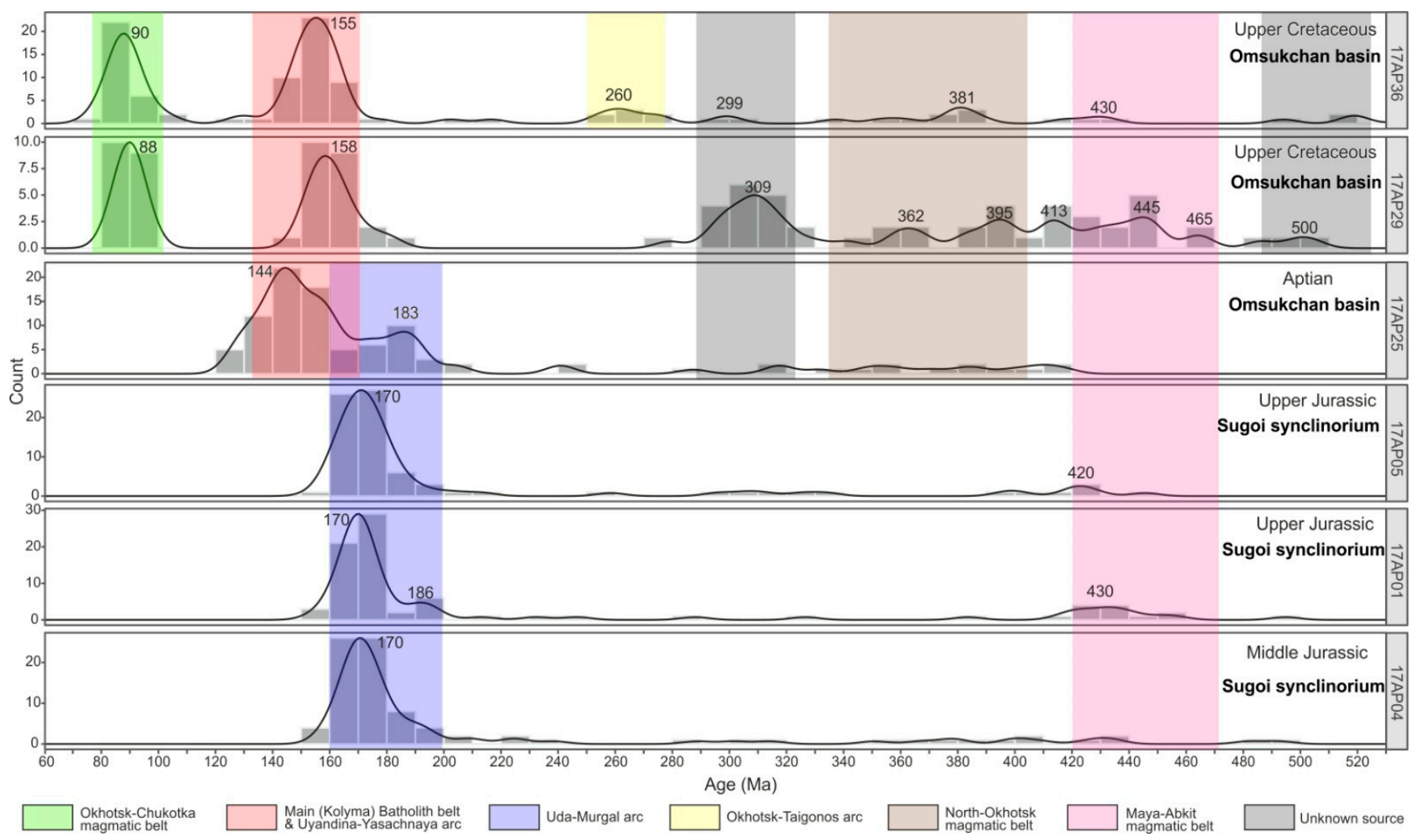

Figure 9. Kernel Density Estimation (KDE) plot showing young (60-530 Ma) U-Pb detrital zircon data from the MiddleUpper Jurassic and Cretaceous samples analyzed in this paper. The Main sources of detrital zircons are shown in color.
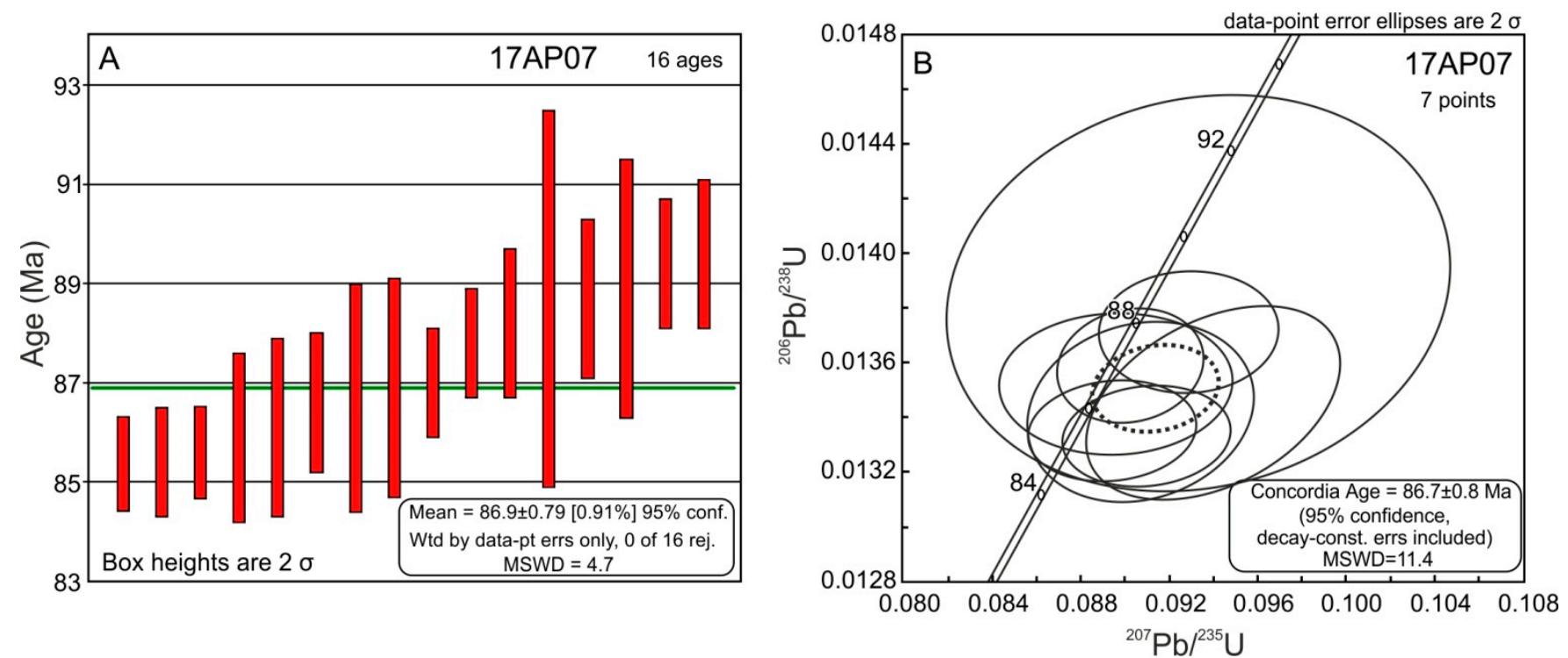

Figure 10. Age of alkaline granite porphyry from the Arangass pluton: (A) Weighted average of LA-ICP-MS U-Pb zircon dating (86.9 $\pm 0.79 \mathrm{Ma}, 16$ grains). (B) Concordia plot of LA-ICP-MS U-Pb analyses from sample 17AP07. Ellipses overlap concordia and each other with a concordia age [106,107] of $86.7 \pm 0.8 \mathrm{Ma}$ (small dotted ellipse) (7 zircon grains).

\section{Discussion}

The distributions of detrital zircon U-Pb ages from three Jurassic rocks of the Sugoi synclinorium exhibit very similar provenance signatures (Figures 8 and 9). Precambrian zircons are not abundant, represent a subsidary component of the zircon population 
$(<28-10 \%)$ (Figure 8), and cluster predominantly between 1800-2000 and 2500-2800 Ma. Metamorphic complexes in the basement of the Omolon Terrane, located to the north-east of the Sugoi synclinorium, represent a possible source for the Archean and Paleoproterozoic zircons (e.g., [26,108,109]) (Figures 2 and 3). Zircons of these ages could also be sourced from the southern part of the Prikolyma Terrane, based on comparable derital zircon age signatures (1750-2800 Ma) in Devonian-Carboniferous strata from that region [21]. The Maya-Abkit Magmatic belt, in the eastern part of the Omulevka Terrane [31] and Omolon-Taigonos area [34], possibly represents the source area for the 420-430 Ma old zircon (Figures 8 and 9). Zircons of comparable ages have also been reported from DevonianCarboniferous clastic rocks across the southern part of the Prikolyma Terrane [21].

The Majority of the dated zircon grains (60-77\%) from Jurassic strata cluster at $170 \mathrm{Ma}$ (Figure 9). Hence, the Main clastic provenance signal points to sourcing from Middle Jurassic felsic Magmatic rocks located close to the Sugoi synclinorium. Early-Middle Jurassic volcanic and volcaniclastic rocks have only been reported from the Uda-Murgal Magmatic arc, located to the south of the Sugoi basin. However, the Late Paleozoic-Early Mesozoic rocks of the Uda-Murgal arc are dominated by andesites and basalts, with a conspicious absence of felsic rocks (e.g., [2,54,55]). This implies a paucity of zircons, Manifested by the absence of Middle Jurassic detrital zircon U-Pb age dates from the Uda-Murgal Magmatic arc in the eastern part of the Verkhoyansk-Kolyma orogenic belt [1]. The nearest well-dated Early-Middle Jurassic basaltic andesites, andesites and granites have been reported from the south-western Margin of the Uda-Murgal arc (Uda Gulf of the Sea of Okhotsk [63,64]), $1400 \mathrm{~km}$ to the south-west of the Sugoi basin. Our new detrital zircon U-Pb data, characterized by an abundance of Middle Jurassic zircons, indicate that Middle Jurassic Magmatic activity occurred within the Uda-Murgal arc, but that felsic Magmatic rocks have either been subsequently eroded or are now completely buried beneath younger Cretaceous rocks of the Okhotsk-Chukotka Magmatic belt. These findings strongly support the hypothesis that the Sugoi basin represented a back-arc basin of the Uda-Murgal arc. Subordinate components of Precambrian and Paleozoic detrital zircons were likely derived from minor erosional input from continental terranes framing the Sugoi basin to the north, west, and east (in present-day coordinates).

Aptian rocks of the Omsukchan basin are characterized by dominant zircon peaks at 144 and $183 \mathrm{Ma}$, implying erosion and sourcing of first-cycle volcanic rocks from the Main (Kolyma) Magmatic belt and the Uyandina-Yasachnaya arc, along with the Uda-Murgal arc, respectively. In addition, these Aptian strata show a greater abundance of Paleozoic and Precambrian grains in comparison with Jurassic strata of the Sugoi basin, pointing to input from the continental Omolon, Prikolyma, and Omulevka terranes (Figures 8 and 9). An increase in erosion rates across the Kolyma-Omolon Superterrane, Main (Kolyma) Magmatic belt, and Uyandina-Yasachnaya arc can be attributed to the final collisional phase between the Kolyma-Omolon Superterrane and Siberia. This is consistent with zircon (U-Th)/He thermochronometric data from the southern part of the Prikolyma Terrane, confirming an episode of rapid cooling and exhumation at $137 \mathrm{Ma}$ [110]. The Omsukchan basin most likely represented an Early Cretaceous [95-98] small rift, oriented orthogonal to the Uda-Murgal arc. In contrast to the Jurassic deposits of the Sugoi basin, the Lower Cretaceous strata of the Omsukchan basin do not contain abundant Middle Jurassic zircons, implying that erosion of Jurassic sedimentary strata and coeval volcanics did not extensively contribute to the clastic provenance in the Early Cretaceous.

The source area of clastics within the Omsukchan rift basin dramatically changed in the latest Cretaceous. These Late Cretaceous strata are characterized by dominant components of Late Jurassic (155-158 Ma) and early Late Cretaceous (88-90 Ma) detrial zircons (Figures 8 and 9). The Late Jurassic (155-158 Ma) component correlates with Magmatic rocks reported from the Main (Kolyma) batholith belt and volcanic rocks of the UyandinaYasachnaya arc (Figure 1) (e.g., $[1,48,52,53])$. The youngest, syn-depositional detrial zircon peak at 88-90 Ma (Figures 8 and 9) Matches the ages of volcanic rocks, volcaniclastic rocks, and granitoid plutons of the Okhotsk-Chukotka Magmatic belt (Figure 1) (e.g., [1]). 
Granite porphyry of the Arangass pluton yielded a similar age (86-87 Ma; this study) and was intruded during the final phases of Magmatic activity within the Okhotsk-Chukotka volcanic belt (e.g., $[1,81,86])$.

Erosional unroofing of terranes along the south-eastern Margin of the Kolyma-Omolon Superterrane significantly increased during the Late Cretaceous, which was possibly related to a second episode of cooling starting at $104 \mathrm{Ma}$, as reported by zircon (U-Th)/He ages from the Prikolyma Terrane [110]. Paleoproterozoic detrital zircons, with predominant age peaks at 1860-2050 Ma, were likely derived from metamorphic basement complexes in the Omolon Terrane $[26,108,109]$ (Figure 8) or could alternatively have been recycled from Devonian-Carboniferous sedimentary strata deposited across the southern part of the Prikolyma Terrane [21]. The Ordovician-Silurian zircons were possibly sourced from the Maya-Abkit Magmatic belt (Figures 8 and 9), which contains volcanic rocks dated at 433-425 $\mathrm{Ma}$ and $440 \pm 2 \mathrm{Ma}$ in the Omolon-Taigonos area [34] and in the Rassokha block of the Omulevka Terrane [31], respectively (Figures 1 and 2). Alternatively, abundant 425-450 Ma zircons have also been reported from Emsian-Eifelian sandstones of southern Prikolyma [21] and could also be the source of similarly aged zircons in the Omsukchan basin. The potential sources for Devonian-Carboniferous detrital zircons could be Devonian-Early Carboniferous subduction-related volcanic rocks of the Kedon Complex and co-magmatic felsic intrusions within the North Okhotsk Magmatic arc [27-30], which have a widespread distribution across the Omolon Terrane. Alternatively, these zircons could also be sourced from Magmatic rocks from the Uvyazka block in the northeastern part of the Omulevka Terrane (395 $\pm 2.9 \mathrm{Ma}, \mathrm{U}-\mathrm{Pb}$, [32]), or from reworking of Devonian-Carboniferous strata across the Prikolyma Terrane, where 333-405 Ma zircons are abundant [21]. Potential sources of the subordinate $\sim 260$ Ma zircon age component are the Okhotsk-Taigonos volcanic arc or erosion and reworking of Late Permian clastic rocks from the Balygychan (Ayan-Yuryakh) anticlinorium [61] (Figures 1 and 2).

The provenance areas for the 299-309 and 500 Ma old detrital zircons remains enigmatic due to an absence of documented coeval Magmatic and tectonic events across the north-east Asia active Margin [1].

Two samples (17AP29 and 17AP36) were collected from the Monkhaidyn Formation, previously considered as Late Carboniferous-Early Permian [105], but which our data have conclusively shown to be Late Cretaceous in age. The young detrital zircon modes indicate Coniacian (17AP29) and Campanian (17AP36) Maximum depositional age estimates. The presence of these Cretaceous ages provide evidence for a northward extent of the Omsukchan basin for more than $35 \mathrm{~km}$, covering the south-eastern part of the Prikolyma Terrane (Figures 2 and 3).

Jurassic strata of West Verkhoyansk and the In'yaly-Debin synclinorium are dominated by detrital zircon U-Pb age components of 280-287 Ma, $480 \mathrm{Ma}$, and 1830-1960 Ma (Figure 11), indicative of source areas located along the southern Margin of the Siberian continent [90,111]. The absence of Neoproterozoic and Mesoproterozoic grains is a diagnostic Manifestation of the "Siberian Gap" [111,112]), representing a period of tectonic quiescence during formation of the Siberian Craton basement [90,111]. Furthermore, Jurassic rocks of the West Verkhoyansk area and the In'yaly-Debin synclinorium were deposited by the paleo-Lena River on the Verkhoyansk passive Margin of Siberia $[90,111]$. In contrast, the Main source regions for clastic Jurassic strata of the Sugoi synclinorium and Cretaceous rocks of the Omsukchan basin were the Magmatic belts associated with the north-east Asian active Margin and, to a lesser extent, with continental blocks of the Kolyma-Omolon Superterrane (Figure 12). 

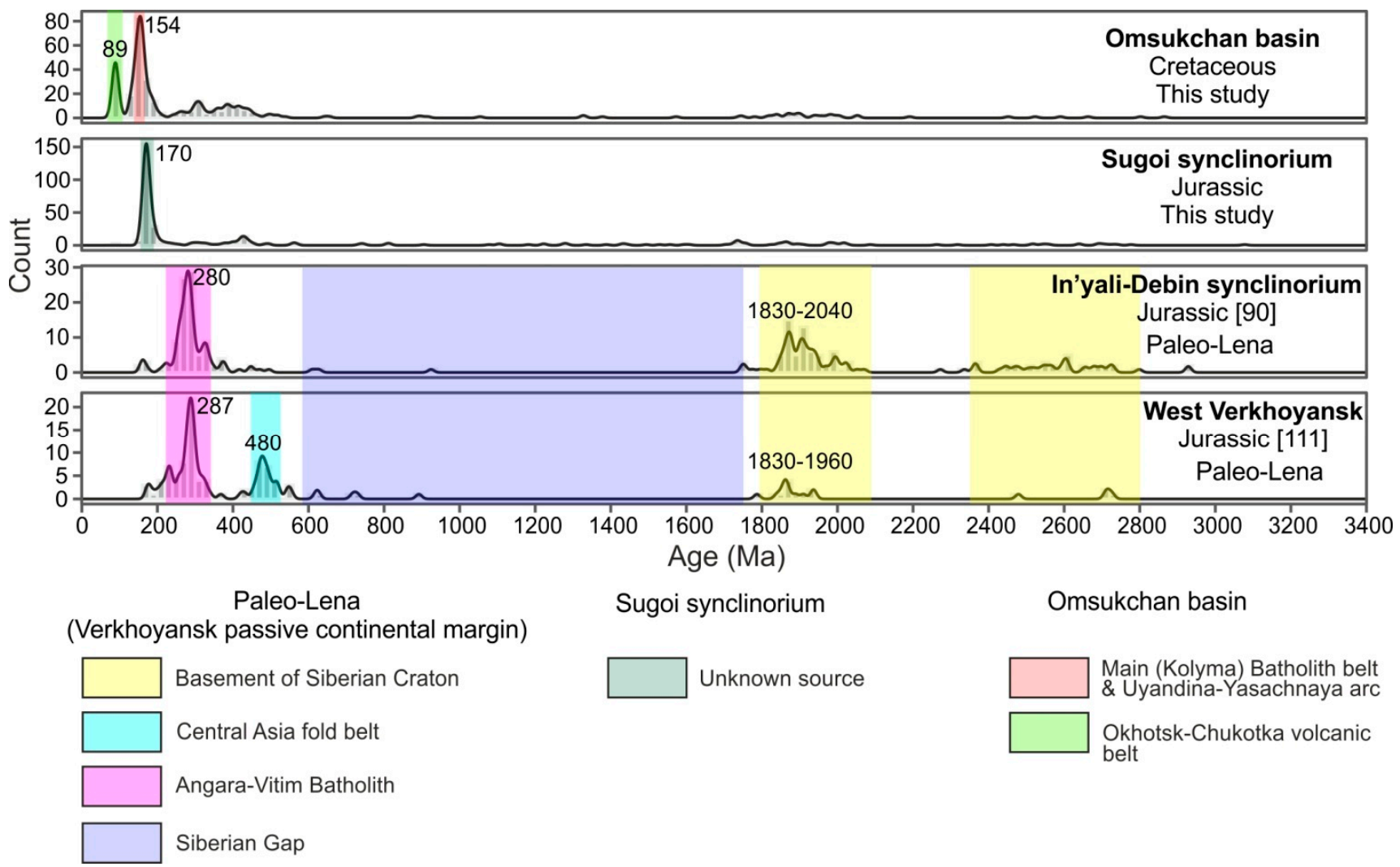

\section{Omsukchan basin}

Main (Kolyma) Batholith belt \& Uyandina-Yasachnaya arc

Okhotsk-Chukotka volcanic belt

Figure 11. Comparison between detrital zircon ages from Jurassic sandstones of West Verkhoyansk, In'yaly-Debin synclinorium, Sugoi synclinorium, and Cretaceous rocks of the Omsukchan basin. The Main sources of detrital zircons are shown in color.

A

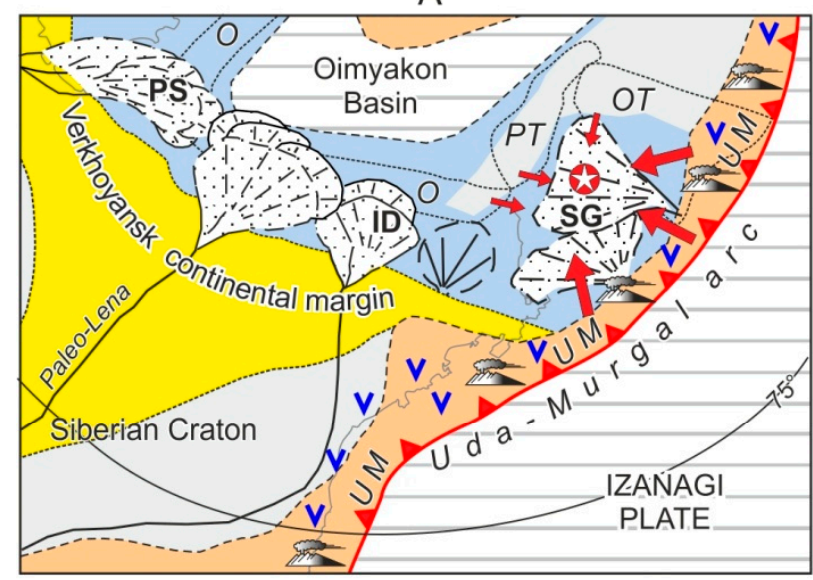

0
B

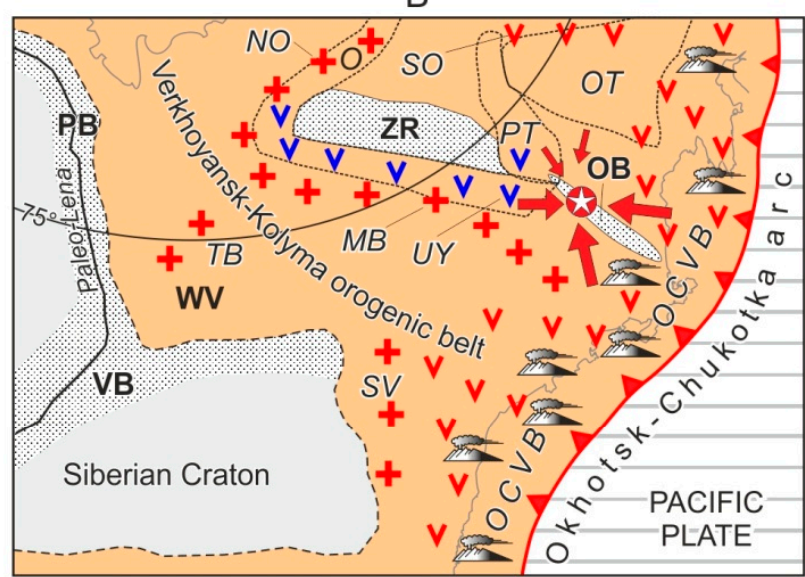

$1000 \mathrm{~km}$
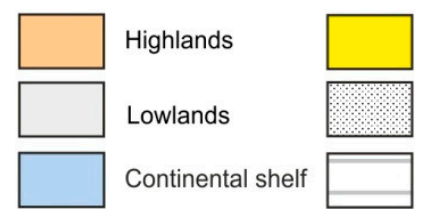
Coastal plain

Cretaceous sedimentary $\&$ volcaniclastic basins

Oceanic crust
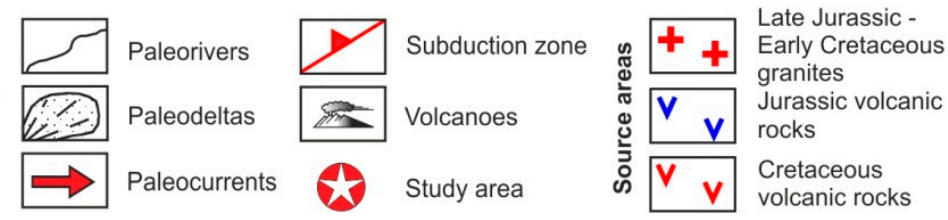

Figure 12. Palaeogeographic Maps of NE Asia for the Middle-early Late Jurassic (A) and Hauterivian-Late Cretaceous (B) (modified from [6,111,113]). Main Jurassic and Cretaceous sedimentary basins: SG—Sugoi, OB-Omsukchan, ID— In'yali-Debin, PS—Polousnyi, VB_-Vilyui, PB—Priverkhoyansk, ZR—Zyryanka. Terranes: PT—Prikolyma, OT—Omolon, O-Omulevka, WV—West Verkhoyansk. Magmatic belts: UM-Uda-Murgal, OCVB-Okhotsk-Chukotka, UY—UyandinaYasachnaya, MB-Main (Kolyma), NB-Northern, SO—Svyatoi Nos-Oloy, SV—South Verkhoyansk. 


\section{Conclusions}

$\mathrm{U}-\mathrm{Pb}$ dating of detrital zircons from Middle-Upper Jurassic clastic rocks of the Sugoi synclinorium and Cretaceous clastic and volcaniclastic rocks of the Omsukchan basin across the south-eastern Verkhoyansk-Kolyma orogenic belt has revealed new insights regarding the Mesozoic tectonic and paleogeographic evolution of the area. The salient insights and conclusions are:

1. Middle-Upper Jurassic rocks of the Sugoi back-arc basin were likely sourced from the Uda-Murgal arc;

2. The Uda-Murgal arc comprised Early-Middle Jurassic felsic Magmatic rocks, which were either subsequently eroded or completely buried beneath younger Cretaceous rocks of the Okhotsk-Chukotka Magmatic belt;

3. Aptian deposits were Mainly sourced from the Main (Kolyma) batholith belt and Uyandina-Yasachnaya arc;

4. A Major change in provenance occurred during the Late Cretaceous in the Omsukchan basin, as reflected by the arrival of clastic input derived from granitoids of the Main (Kolyma) batholith belt, volcanic, and plutonic rocks of the Uyandina-Yasachnaya and Okhotsk-Chukotka arcs and with a significant addition of clastic Material from the uplifted Kolyma-Omolon Superterrane;

5. Comparison of detrital zircon U-Pb age distributions of Mesozoic rocks in the Sugoi and Omsukchan sedimentary basins suggests that they were not deposited along the Verkhoyansk passive continental Margin of Siberia;

6. Our data allow us to assign new depositional ages to non-fossiliferous volcaniclastic rocks across the south-eastern Prikolyma Terrane and revise Late CarboniferousEarly Permian to Late Cretaceous. As a consequence, the northern boundary of the Omsukchan basin should be moved farther northward, covering older deformed rocks of the Prikolyma Terrane;

7. This study provides new insights into the evolution of sedimentary basins and their relations to Magmatic belts across the north-east Asia active Margin and could be used to inform larger scale paleotectonic and paleogeographic reconstructions of NE Asia.

\section{Future Work}

The Jurassic-Cretaceous provenance models proposed here are based on $\mathrm{U}-\mathrm{Pb}$ dating of detrital zircons and sandstone petrography. Further work to study Mesozoic sedimentation requires acquiring additional $\mathrm{U}-\mathrm{Pb}$ zircon data from Triassic, Jurassic, and Cretaceous clastic and volcaniclastic rocks of this region, accompanied by geochemistry of Magmatic rocks and Lu-Hf study of detrital zircons. This will subsequently improve our understanding of the Mesozoic history of the north-east Asia active Margin.

Supplementary Materials: The following are available online at https:/ / www.mdpi.com/2075-163 X/11/3/291/s1, Table S1: Results of U-Pb dating of detrital zircons.

Author Contributions: A.V.P., investigation, writing—original draft preparation; V.B.E., investigation, editing; D.F.S., investigation, editing. All authors have read and agreed to the published version of the Manuscript.

Funding: U-Pb dating was supported by the project "Changes at the Top of the World through Volcanism and Plate Tectonics: A Norwegian-Russian-North American collaboration in Arctic research and education: NOR-R-AM 2". Interpretation of isotopic data of Jurassic rocks was supported by the Russian Science Foundation (grant No. 20-17-00169). Interpretation of isotopic data of Cretaceous rocks and interpretation of isotopic data was supported by the Russian Foundation for Basic Research (RFBR) (grant No. 19-05-00945). Field work was partly supported by DPMGI SB RAS (project No. 0381-2019-0001).

Data Availability Statement: Not applicable. 
Acknowledgments: The authors are most grateful to Vladimir Shpikerman and Vasiliy Proskurnin (Karpinskiy Russian Geological Research Institute, St. Petersburg, Russia) for their help in conducting field work. We would like to thank Lisa Stockli for analytical assistance. We thank three anonymous reviewers for their constructive comments, suggestions, and corrections, which very much helped to improve the Manuscript. We are grateful to James Barnet for correcting the English.

Conflicts of Interest: The authors declare no conflict of interest.

\section{References}

1. Akinin, V.V.; Miller, E.L.; Toro, J.; Prokopiev, A.V.; Gottlieb, E.S.; Pearcey, S.; Polzunenkov, G.O.; Trunilina, V.A. Episodicity and the dance of late Mesozoic Magmatism and deformation along the northern circum-Pacific Margin: North-eastern Russia to the Cordillera. Earth Sci. Reviews. 2020, 208, 103272. [CrossRef]

2. Parfenov, L.M. Continental Margins and Island Arcs of the Mesozoides of Northeastern Asia; Nauka: Novosibirsk, Russia, 1984. (In Russian)

3. Parfenov, L.M. Tectonics of the Verkhoyansk-Kolyma mesozoides in the context of plate-tectonics. Tectonophysics 1991, 139, 319-342. [CrossRef]

4. Belyi, V.F. Geology of the Okhotsk-Chuklotka Volcanic Belt; Northeast Interdisciplinary Science Research Institute: Magadan, Russia, 1994. (In Russian)

5. Tectonics, Geodynamics and Metallogeny of the Sakha Republic (Yakutia); Parfenov, L.M.; Parfenov, M.I. (Eds.) MaIK Nauka/Inteperiodica: Moscow, Russia, 2001. (In Russian)

6. Parfenov, L.M.; Berzin, N.A.; Khanchuk, A.I.; Badarch, G.; Belichenko, V.G.; Bulgatov, A.N.; Dril', S.I.; Kirillova, G.L.; Kuz'min, M.I.; Nokleberg, W.; et al. Model for the formation of orogenic belts of Central and Northeastern Asia. Tikhookeanskaya Geol. 2003, 6, 7-42. (In Russian)

7. Şengör, A.M.; Natal'in, B.A. Palaeotectonics of Asia: Fragments of a synthesis. In The Tectonic Evolution of Asia; Yin, A., Harrison, M., Eds.; Rubey Colloquium; Cambridge University Press: Cambridge, UK, 1996; pp. 486-640.

8. Nokleberg, W.J.; Parfenov, L.M.; Monger, J.W.H.; Norton, I.O.; Khanchuk, A.I.; Stone, D.B.; Scotese, C.R.; Scholl, D.W.; Fujita, K. Phanerozoic Tectonic Evolution of the Circum-North Pacific. Professional Paper 1626; U.S. Geological Survey (USGS): Reston, VA, USA, 2001.

9. Metallogenesis and Tectonics of Northeast Asia. Professional Paper 1765; Nokleberg, W.J. (Ed.) U.S. Geological Survey (USGS): Reston, VA, USA, 2010.

10. Parfenov, L.M.; Badarch, G.; Berzin, N.A.; Khanchuk, A.I.; Kuzmin, M.I.; Nokleberg, W.J.; Prokopiev, A.V.; Ogasawara, M.; Yan, H. Summary of Northeast Asia geodynamics and tectonics. Stephan Mueller Spec. Publ. Ser. 2009, 4, 11-33. [CrossRef]

11. Geodynamics, Magmatism, and Metallogeny of Eastern Russia; Khanchuk, A.I. (Ed.) Dal'nauka: Vladivostok, Russia, 2006. (In Russian)

12. Toro, J.; Miller, E.L.; Prokopiev, A.V.; Zhang, X.; Veselovskiy, R. Mesozoic orogens of the Arctic from Novaya Zemlya to Alaska. J. Geol. Soc. 2016, 173, 989-1006. [CrossRef]

13. Natal'in, B.A. Early Mesozoic Folded Belts in the North Part of the Pacific Rim; Nauka: Moscow, Russia, 1984. (In Russian)

14. Natal'in, B.A. Mesozoic accretionary and collisional tectonics of the USSR south Far East. Geol. Pac. Ocean 1991, 5, 3-23.

15. Sokolov, S.D.; Bondarenko, G.Y.; Morozov, O.L.; Shekhovtsov, V.A.; Glotov, S.P.; Genelin, A.V.; Kravchenko-Berezhnoy, I.R. South Anyui suture, northeast Arctic Russia: Facts and problems. In Tectonic Evolution of the Bering Shelf-Chukchi Sea-Arctic Margin and Adjacent Landmasses; Miller, E.L., Grantz, A., Klemperer, S.L., Eds.; Geological Society of America: Boulder, CO, USA, 2002; pp. 209-224.

16. Sokolov, S.D. Tectonics of northeast Asia: An overview. Geotectonics 2010, 44, 493-509. [CrossRef]

17. Amato, J.M.; Toro, J.; Akinin, V.V.; Hampton, B.A.; Salnikov, A.S.; Tuchkova, M.I. Tectonic evolution of the Mesozoic South Anyui suture zone, eastern Russia: A critical component of paleogeographic reconstructions of the Arctic region. Geosphere 2015, 11, 1530-1564. [CrossRef]

18. Prokopiev, A.V.; Ershova, V.B.; Anfinson, O.; Stockli, D.; Powell, J.; Khudoley, A.K.; Vasiliev, D.A.; Sobolev, N.N.; Petrov, E.O. Tectonics of the New Siberian Islands Archipelago: Structural styles and low-temperature thermochronology. J. Geodyn. 2018, 121, 155-184. [CrossRef]

19. Sokolov, S.D.; Bondarenko, G.Y.; Khudoley, A.K.; Morozov, O.L.; Luchitskaya, M.V.; Tuchkova, M.I.; Layer, P.W. Tectonic reconstruction of Uda-Murgal arc and the Late Jurassic and Early Cretaceous convergent Margin of Northeast Asia-Northwest Pacific. Stephan Mueller Spec. Publ. Ser. 2009, 4, 273-288. [CrossRef]

20. Khanchuk, A.I.; Grebennikov, A.V.; Ivanov, V.V. Albian-Cenomanian orogenic belt and igneous province of Pacific Asia. Russ. J. Pac. Geol. 2019, 13, 187-219. [CrossRef]

21. Prokopiev, A.V.; Ershova, V.B.; Stockli, D.F. Provenance of the devonian-Carboniferous clastics of the southern part of the Prikolyma terrane (Verkhoyansk-Kolyma orogen) based on U-Pb dating of detrital zircons. GFF 2019, 141, 272-278. [CrossRef]

22. Shishkin, V.A. Metamorphic Complex of the Prikolyma Uplift; Nauka: Moscow, Russia, 1979. (In Russian)

23. Grinberg, A.G.; Gusev, G.S.; Bakharev, A.G.; Bulgakova, M.D.; Ipatieva, I.S.; Nedosekin, Y.D.; Rukovich, V.N.; Soloviev, V.I.; Surnin, A.A.; Tretyakov, F.F. Tectonics, Magmatic and Metamorphic Complexes of the Kolyma-Omolon Massif; Nauka: Moscow, Russia, 1981. (In Russian)

24. Tretyakov, F.F. Evolution of Tectonic Structures in the Kolyma Massif; YaF SO AN SSSR: Yakutsk, Russia, 1987. (In Russian) 
25. Terekhov, M.I. Stratigraphy and Tectonics of the Southern Part of the Omolon Massif; Nauka: Moscow, Russia, 1979. (In Russian)

26. Akinin, V.V.; Zhulanova, I.L. Age and geochemistry of zircon from the oldest metamorphic rocks of the Omolon Massif (Northeast Russia). Geochem. Int. 2016, 54, 651-659. [CrossRef]

27. Gagieva, A.M.; Zhulanova, I.L. Geochronometry of middle paleozoic volcanic of the Omolon Massif: Comparison of K-Ar, Rb-Sr, and U-Pb data, and their geologic interpretation (North-East Asia). Tikhookeanskaya Geol. 2011, 30, 3-19. (In Russian) [CrossRef]

28. Goryachev, N.A.; Egorov, V.N.; Savva, N.E.; Kuznetsov, V.M.; Fomina, M.I.; Rozhkov, P.Y. Geology and Metallogeny of Phanerozoic Assemblages of Southern Omolon Microcontinent; Dal'nauka: Vladivostok, Russia, 2017. (In Russian)

29. Glukhov, A.N.; Kotov, A.B.; Priymenko, V.V.; Sal'nikova, E.B.; Kuznetsov, A.B.; Podol'skaya, M.M. New age data of the Bulun complex (Omolon Massif). In Transactions of the All-Russian Meeting "Geology and Mineral Resources of the Northeast Russia"; Publishing House NEFU: Yakutsk, Russia, 2019; pp. 27-30. (In Russian)

30. Akinin, V.V.; Glukhov, A.N.; Kotov, A.B.; Alshevsky, A.V.; Priymenko, V.V.; Polzunenkov, G.O. New data on the age of the Kedon volcanic belt of the Omolon Massif (Northeast Asia). In Fundamental Problems of Tectonics and Geodynamics. Volume 1. Materials of the LII Tectonic Meeting; GEOS: Moscow, Russia, 2020; pp. 175-178. (In Russian)

31. Sychev, S.N.; Khudoley, A.K.; Lebedeva, O.Y.; Rogov, A.V.; Sokolov, S.D.; Chamberlain, K.R.; Maklashin, V.S.; Lvov, P.A. Silurian granitoid Magmatism of the Rassokha terrane (North-East Russia). Dokl. Earth Sci. 2020, 494, 762-766. [CrossRef]

32. Prokopiev, A.V.; Toro, J.; Bakharev, A.G.; Miller, E.L.; Wooden, J.; Surnin, A.A. The Uvyazka paleorift zone: First U-Pb SHRIMP geochronological data. Otechestvennaya Geol. 2007, 5, 30-33. (In Russian)

33. Kuzmin, V.K.; Belyatsky, B.V.; Naumov, M.V. New isotope-geochronological data on the late Ordovician age of granitoids in the western part of the Okhotsk Massif (Upper Maya uplift). Reg. Geol. Metallog. 2003, 19, 101-105. (In Russian)

34. Akinin, V.V.; Polzunenkov, G.O.; Al'shevsky, A.V.; Alekseev, D.I.; Kuznetsov, B.M.; Proskurnin, V.F. Evolution of Magmatism within Omolon-Taigonos block. In Proceedings of the International Conference of Arctic Margins VIII, Abstracts, Stockholm, Sweden, 11-14 June 2018; Available online: https: / /icamviii.geo.su.se/en/all-abstracts (accessed on 13 June 2018).

35. Khudoley, A.K.; Prokopiev, A.V.; Chamberlain, K.R.; Ernst, R.E.; Jowitt, S.M.; Malyshev, S.V.; Zaitsev, A.I.; Kropachev, A.P.; Koroleva, O.V. Early Paleozoic Mafic Magmatic events on the eastern Margin of the Siberian Craton. Lithos 2013, 174, 45-56. [CrossRef]

36. Khudoley, A.K.; Prokopiev, A.V.; Chamberlain, K.R.; Savelev, A.D.; Ernst, R.E.; Malyshev, S.V.; Moskalenko, A.N.; Lebedeva, O.Y. Late Ordovician Mafic Magmatic event, Southeast Siberia: Tectonic implications, LIP interpretation, and potential link with a Mass extinction. Minerals 2020, 10, 1108. [CrossRef]

37. Khudoley, A.K.; Prokopiev, A.V. Magmatism and tectonic evolution of the southeastern Margin of the Siberian craton in the Ordovician. In Petrology of Magmatic and Metamorphic Complexes, Issue 10. Transactions of the X All Russian Petrographic Conference Attended by International Participants; Tomsk TsNTI Publisher: Tomsk, Russia, 2018; pp. 409-415. (In Russian)

38. Surmilova, E.P.; Maximova, G.A. State Geological Map of the USSR, Scale 1:200,000, Sheet Q-53-XXIX, XXX (Mouth of Bulkut River). Srednekolymsk Series. Explanation Text; Aerogeologiya Press: Moscow, Russia, 1987. (In Russian)

39. Lychagin, P.P.; Dylevsky, E.F.; Shpikerman, V.I.; Likman, V.B. Magmatism of Central Regions of the North-East USSR; DVO AN SSSR: Vladivostok, Russia, 1989. (In Russian)

40. Shpikerman, V.I. Pre-Cretaceous Minerageny of North-Eastern Asia; NEISRI, Far Eastern Branch of the Russian Academy of Science Press: Magadan, Russia, 1998. (In Russian)

41. Badarch, G.; Dejidmaa, G.; Gerel, O.; Obolenskiy, A.A.; Prokopiev, A.V.; Timofeev, V.F.; Nokleberg, W.J. Chapter 6. Devonian through early Carboniferous (Mississippian) metallogenesis and tectonics of Northeast Asia. In Metallogenesis and Tectonics of Northeast Asia. Professional Paper 1765; Nokleberg, W.J., Ed.; U.S. Geological Survey (USGS): Reston, VA, USA, 2010; pp. 6-1-6-56.

42. Tuchkov, I.I.; Andrianova, V.A. New data on effusive rocks in the upper Maya river. In Petrography and Mineralogy of Sedimentary Formations of Yakutia; Yakutian Publishing House: Yakutsk, Russia, 1972; pp. 87-97. (In Russian)

43. Umitbaev, R.B. Geological formations of the Okhotsk median Massif. In Tectonics of the Eastern Soviet Asia; DVO AN SSSR: Vladivostok, Russia, 1976; pp. 73-95. (In Russian)

44. Chikov, B.M. Median Massifs and Problems of Tectonic Zoning of Orogenic Belts; Nauka: Novosibirsk, Russia, 1978. (In Russian)

45. Prokopiev, A.V.; Toro, J.; Hourigan, J.K.; Bakharev, A.G.; Miller, E.L. Middle paleozoic-mesozoic boundary of the North Asian craton and the Okhotsk terrane: New geochemical and geochronological data and their geodynamic interpretation. Stephan Mueller Spec. Publ. Ser. 2009, 4, 71-84. [CrossRef]

46. Trunilina, V.A. Main batholitic belt. In Tectonics, Geodynamics and Metallogeny of the Sakha Republic (Yakutia); Parfenov, L.M., Kuz'min, M.I., Eds.; MaIK Nauka/Interperiodica: Moscow, Russia, 2001; pp. 256-258. (In Russian)

47. Trunilina, V.A.; Roev, S.P.; Orlov, Y.S. Volcanic-Plutonic Belts of North-East Yakutia; Sachapoligrafizdat: Yakutsk, Russia, 2007. (In Russian)

48. Akinin, V.V.; Prokopiev, A.V.; Toro, J.; Miller, E.L.; Wooden, J.; Goryachev, N.A.; Alshevsky, A.V.; Bakharev, A.G.; Trunilina, V.A. $\mathrm{U}-\mathrm{Pb}$ SHRIMP ages of granitoids from the Main batholith belt (North East Asia). Dokl. Earth Sci. 2009, 426, 605-610. [CrossRef]

49. Parfenov, L.M.; Natapov, L.M.; Sokolov, S.D.; Tsukanov, N.V. Terranes and accretionary tectonics of northeastern Asia. Geotectonics 1993, 1, 68-78.

50. Layer, P.W.; Newberry, R.; Fujita, K.; Parfenov, L.M.; Trunilina, V.A.; Bakharev, A.G. Tectonic setting of the plutonic belts of Yakutia, Northeast Russia, based on ${ }^{40} \mathrm{Ar} /{ }^{39} \mathrm{Ar}$ and trace element geochemistry. Geology 2001, 29, 167-170. [CrossRef]

51. Ged'ko, M.I. The late Jurassic Uyandina-Yasachnaya island-arc (northeast USSSR). Geotectonics 1988, 22, $263-273$. 
52. Prokopiev, A.V.; Toro, J.; Miller, E.L.; Bakharev, A.G.; Trunilina, V.A.; Wooden, J.; Surnin, A.A. Granitoids of the Main batholith belt and volcanics of Uyandina-Yasachnaya arc (Northeast Asia): New U-Pb SHRIMP geochronological and geochemical data. In Large Igneous Provinces of Asia, Mantle Plumes and Metallogeny; Publishing House of SB RAS: Novosibirsk, Russia, 2007; pp. 51-54. (In Russian)

53. Sychev, S.N.; Lebedeva, O.Y.; Mironovich, A.S.; Rogov, A.V.; Maklashin, V.S. Results of petrographic and isotope-geochronological studies of granitoids of the Rassokha Massif (Omulevka uplift, east Yakutia). In Topical Problems of the Earth Sciences in the Concept of Stable Development of Byelorussia and Adjacent States, Proceedings of the 5-th International Scientific-Practical Conference, Gomel, Belarus, 28-29 November 2019; F. Scorina GSU: Gomel, Belarus, 2019; pp. 49-54. (In Russian)

54. Filatova, N.I. Peri-Oceanic Volcanic Belts; Nedra: Moscow, Russia, 1988. (In Russian)

55. Zaborovskaya, N.B. The Inner Zone of the Okhotsk-Chukotka Belt on Taigonos; Nauka: Moscow, Russia, 1978. (In Russian)

56. Sokolov, S.D. Accretionary Tectonics of the Koryak-Chukotka Segment of the Pacific Belt. Trans. of Geological Institute Russian Academy of Sciences, 479; Nauka: Moscow, Russia, 1992. (In Russian)

57. Korostelev, V.I. Geology and Tectonics of the South Verkhoyansk Region; Nauka: Novosibirsk, Russia, 1982. (In Russian)

58. Prokopiev, A.V.; Bakharev, A.G.; Gamyanin, G.N.; Zaitsev, A.I. Interference of synchronous geodynamic events (on the example of the Verkhoyansk-Kolyma mesozoids). In Tectonics, Deep Structure and Minerageny of East Asia; Institute of Tectonics and Geophysics of FEB RAS: Khabarovsk, Russia, 2006. (In Russian)

59. Biakov, A.S.; Prokopiev, A.V.; Kutygin, R.V.; Vedernikov, I.V.; Budnikov, I.V. Geodynamic environments of formation of Permian sedimentary basins of the Verkhoyansk-Kolyma folded region. Otechestvennaya Geol. 2005, 5, 81-85. (In Russian)

60. Biakov, A.S.; Prokopiev, A.V.; Kutygin, R.V.; Vedernikov, I.L.; Budnikov, I.V. Geodynamic environments of Permian sedimentary basins in the Verkhoyansk-Kolyma folded region. In Tectonics and Metallogeny of the Circum-North Pacific and Eastern Asia; Institute of Tectonics and Geophysics, Far East Branch of the Russian Academy of Sciences: Khabarovsk, Russia, 2007 ; pp. 79-81. (In Russian)

61. Biakov, A.S.; Goryachev, N.A.; Vedernikov, I.L.; Brynko, I.V.; Tolmacheva, E.V. New results of U-Pb SHRIMP dating of zircons from upper Wuchiapingian (Upper Permian) deposits in northeastern Russia. Dokl. Earth Sci. 2017, 477, 1348-1352. [CrossRef]

62. Tikhomirov, P.L.; Pravikova, N.V.; Bychkova, Y.V. The Chukchi segment of the Uda-Murgal and Okhotsk-Chukotka volcanic belts: Age and tectonic environment. Russ. Geol. Geophys. 2020, 4. [CrossRef]

63. Sorokin, A.A.; Sorokin, A.P.; Ponomarchuk, V.A.; Travin, A.V. Early Jurassic volcanics of the Uda belt (southeastern part of the North Asian craton): ${ }^{40} \mathrm{Ar} /{ }^{39} \mathrm{Ar}$ geochronological and geochemical data. Dokl. Earth Sci. 2015, 460, 6-10. [CrossRef]

64. Larin, A.M.; Kotov, A.B.; Salnikova, E.B.; Sorokin, A.A.; Kovach, V.P.; Podolskaya, M.M. Early Jurassic suprasubduction granitoids of the Uda complex at the southwestern end of the Uda-murgal Magmatic arc: New data on the age and sources. Dokl. Earth Sci. 2020, 492, 407-410. [CrossRef]

65. Moiseev, A.V.; Luchitskaya, M.V.; Sokolov, S.D. Volcanic rocks and granitoids from cape svyatoy nos (Eastern Arctic): Their age, composition, and paleotectonic reconstructions. Dokl. Earth Sci. 2020, 492, 398-401. [CrossRef]

66. Kara, T.V. New data on the age of igneous complexes of the Alazey-Oloy foldbelt (Western Chukotka). Russ. J. Pac. Geol. 2018, 12, 549-557. [CrossRef]

67. Kuzmichev, A.B. Where does the South Anyui suture go in the New Siberian Islands and Laptev Sea? Implications for the Amerasia basin origin. Tectonophysics 2009, 463, 86-108. [CrossRef]

68. Katkov, S.M.; Strickland, A.; Miller, E.L.; Toro, J. Age of granite batholiths in the Anyui-Chukotka foldbelt. Dokl. Earth Sci. 2007, 414, 515-518. [CrossRef]

69. Luchitskaya, M.V.; Sokolov, S.D.; Bondarenko, G.E.; Katkov, S.M. Composition and geodynamic setting of granitoid Magmatism in the Alyarmaut uplift, western Chukchi Peninsula. Geochem. Int. 2010, 48, 891-916. [CrossRef]

70. Miller, E.L.; Katkov, S.M.; Strickland, A.; Toro, J.; Akinin, V.V.; Dumitru, T.A. Geochronology and thermochronology of Cretaceous plutons and metamorphic country rocks, Anyui-Chukotka fold belt, northeastern Arctic Russia. Stephan Mueller Spec. Publ. Ser. 2009, 4, 223-241. [CrossRef]

71. Miller, E.L.; Meisling, K.E.; Akinin, V.V.; Brumley, K.; Coakley, B.J.; Gottlieb, E.S.; Hoiland, C.W.; O’Brien, T.M.; Soboleva, A.; Toro, J. Circum-Arctic lithosphere evolution (CALE) transect C: Displacement of the Arctic Alaska-Chukotka microplate toward the Pacific during opening of the Amerasia basin of the Arctic. In Circum-Arctic Lithosphere Evolution. Special Publications 460; Pease, V., Coakley, B., Eds.; Geological Society: London, UK, 2017; pp. 57-120. [CrossRef]

72. Akinin, V.V.; Miller, E.L.; Gottlieb, E.S.; Polzunenkov, G. Cretaceous Magmatism in the Russian sector of The Arctic AlaskaChukotka Microplate (AACHM). In Proceedings of the AGU Fall Meeting, San Francisco, CA, USA, 5-9 December 2011. abstract id: T23B-2379.

73. Tikhomirov, P.L.; Akinin, V.V.; Nakamura, E. Mesozoic Magmatism in the central Chukotka Peninsula: New U-Pb geochronological data and their geodynamic interpretation. Dokl. Earth Sci. 2008, 419, 261-265. [CrossRef]

74. Tikhomirov, P.L.; Kalinina, E.A.; Kobayashi, K.; Nakamura, E. Late mesozoic silicic Magmatism of the North Chukotka area (NE Russia): Age, Magma sources, and geodynamic implications. Lithos 2008, 105, 329-346. [CrossRef]

75. Tikhomirov, P.L.; Luchitskaya, M.V.; Shats, A.L. Age of granitoid plutons, north Chukotka: Problem formulation and new SHRIMP U-Pb zircon datings. Dokl. Earth Sci. 2011, 440, 1363-1366. [CrossRef] 
76. Pease, V.; Wyld, S.; Miller, E.L.; Sokolov, S.; Akinin, V.V.; Wright, J.E. U-Pb zircon geochronology of Cretaceous Magmatism in eastern Chukotka, northeast Russia, and implications for Pacific subduction and the opening of the Canada basin. In Circum-Arctic Lithosphere Evolution. Special Publications 460; Pease, V., Coakley, B., Eds.; Geological Society: London, UK, 2017 ; pp. 159-182. [CrossRef]

77. Luchitskaya, M.V. Granitoid Magmatism and Continental Crust Formation of the Northern Framework of Pacific Ocean in MesozoicCenozoic. Transactions of the Geological Institute. V. 607; GEOS: Moscow, Russia, 2014. (In Russian)

78. Prokopiev, A.V.; Borisenko, A.S.; Gamyanin, G.N.; Pavlova, G.G.; Fridovsky, V.Y.; Kondrat'va, L.A.; Anisimova, G.S.; Trunilina, V.A.; Ivanov, A.I.; Travin, A.V.; et al. Age constraints and tectonic settings of metallogenic and Magmatic events in the Verkhoyansk-Kolyma folded area. Russ. Geol. Geophys. 2018, 59, 1237-1253. [CrossRef]

79. Chernyshev, I.V.; Bortnikov, N.S.; Goltsman, Y.V.; Gamyanin, G.N.; Chugaev, A.V.; Bairova, E.D.; Bakharev, A.G.; Kotov, A.B.; Sal'nikova, E.B. Geochronology of igneous rocks at and near to the Nezhdaninka gold deposit, Yakutia, Russia: U-Pb, Rb-Sr, and Sm-Nd isotopic data. Geol. Ore Depos. 2012, 54, 411-433. [CrossRef]

80. Zonenshain, L.P.; Kuzmin, M.I.; Natapov, L.M.; Page, B.M. Plate Tectonics of the USSR Territory: A plate Tectonic Synthesis; Geodynamics Series; American Geophysical Union: Washington, DC, USA, 1990.

81. Akinin, V.V.; Miller, E.L. Evolution of calc-alkaline Magmas of the Okhotsk-Chukotka volcanic belt. Petrology 2011, 19, 249-290. [CrossRef]

82. Akinin, V.V.; Hourigan, D.; Miller, E.M. New age data on the Ol'skaya formation of the OCVB in the Kheta River basin: Evidence from results of Ar-Ar dating. In Magmatism and Metamorphism of Northeastern Asia; NEISRI FEB RAS: Magadan, Russia, 2000; pp. 82-84. (In Russian)

83. Akinin, V.V.; Hourigan, J.K.; Wright, J.; Miller, E.L.; Mishin, L.F. New data on the age of Okhotsk Chukotka volcanic belt (U-Pb SHRIMP-dating). In Proceedings of the III All Russian Conference on Isotopic Geochronology: Isotopic Dating of Ore Forming Processes, Magmatism, Sedimentation, and Metamorphism, Moscow, Russia, 6-8 June 2006; IGEM RAS: Moscow, Russia, 2006; pp. 22-26. (In Russian).

84. Hourigan, J.K.; Akinin, V.V. Tectonic and chronostratigraphic implications of new 40Ar/39Ar geochronology and geochemistry of the Arman and Maltan-Ola volcanic fields, Okhotsk-Chukotka volcanic belt, northeastern Russia. Geol. Soc. Am. Bull. 2004, 116, 637-654. [CrossRef]

85. Ispolatov, V.O.; Tikhomirov, P.L.; Heizler, M.; Cherepanova, I.Y. New ${ }^{40} \mathrm{Ar} /{ }^{39} \mathrm{Ar}$ ages of Cretaceous continental volcanics from Central Chukotka: Implications for initiation and duration of volcanism within the northern part of the Okhotsk-Chukotka volcanic belt (Northeastern Eurasia). J. Geol. 2004, 112, 369-377. [CrossRef]

86. Tikhomirov, P.L.; Kalinina, E.A.; Moriguti, T.; Makishima, A.; Kobayashi, K.; Nakamura, E. Trace element and isotopic geochemistry of Cretaceous Magmatism in NE Asia: Spatial zonation, temporal evolution, and tectonic controls. Lithos 2016, 264, 453-471. [CrossRef]

87. Kuznetsov, V.M.; Zhigalov, S.V.; Vedernikova, T.A.; Shpikerman, V.I. State Geological Map of the Russian Federation. Scale 1:1,000,000 (Third Generation). Verkhoyansk-Kolyma Series. Sheet P-56—Seimchan. Explanatory Note; VSEGEI: Saint-Petersburg, Russia, 2008. (In Russian)

88. Geologic Map of the USSR. Scale 1:1,000,000 (New Series). Sheet Q-56, 57—Srednekolymsk. Explanatory Note; Natapov, L.M.; Shul'gina, V.S. (Eds.) VSEGEI: Leningrad, Russia, 1991. (In Russian)

89. Geodynamic Map of Yakutia and Adjacent Regions. Scale 1:1 500 000; Parfenov, L.M. (Ed.) GUBK: Yakutsk, Russia, 1994. (In Russian)

90. Prokopiev, A.V.; Miller, E.L.; Toro, J.; Gehrels, G.E.; Soloviev, A.V. Provenance of Mesozoic siliciclastic sequences of the Verkhoyansk continental Margin, the Kular-nera slate belt and the In'yali-Debin synclinorium based on U-Pb ages of detrital zircon suites. In Geophysical Institute Report UAG-R-335; Stone, D.B., Clough, J.G., Thurston, D.K., Eds.; University of Alaska: Fairbanks, AK, USA, 2012; pp. 173-176.

91. Petrov, O.V.; Mikhailov, B.K.; Shevchenko, S.S.; Rosinov, M.I.; Kolesnikov, D.I.; Lokhov, K.I.; Prosolov, E.M.; Prilepskiy, E.B.; Berezhnaya, N.G.; Matukov, D.I.; et al. Isotopic study of the unique Ag-Au ducat deposit (Magadan area, North-East Russia) as a key for understanding of the processes of volcanogenic ore deposition. Reg. Geol. Metallog. 2006, 27, 60-76. (In Russian)

92. Kuznetsov, V.M.; Livach, A.E. Structure and metallogenic zoning of the Balygychan-Sugoi trough. In Problems of Metallogeny of Ore Regions of the North-East of Russia; Northeast Interdisciplinary Science Research Institute: Magadan, Russia, 2005; pp. 156-177. (In Russian)

93. Umitbaev, R.B. Okhotsk-Chauna Metallogenic Province (Structure, Ore Content, Analogs); Nauka: Moscow, Russia, 1986. (In Russian)

94. Kotlyar, I.N.; Rusakova, T.B.; Gagieva, A.M. Buyundino-Sugoi ore concentrating region: A unique metallogenic area of the North-East of Russia. Tikhookeanskaya Geol. 2004, 23, 3-19. (In Russian)

95. Kuznetsov, V.M. Different-order structures of the late Mesozoic tectonomagmatic activation in the Verkhoyansk-Chukotka folded region. Vestn. SVNTs RAN 2006, 2, 2-13. (In Russian)

96. Sidorov, A.A.; Volkov, A.V.; Alekseev, V.Y.; Belyi, V.F.; Kolova, E.E. The gold-silver Okhotsk-Chukotka volcanic belt. Geol. Ore Depos. 2009, 51, 441-455. [CrossRef]

97. Sidorov, A.A.; Volkov, A.V.; Chekhov, A.D.; Savva, N.E. Volcanogenic belts of the Marginal sea lithosphere in the Russian Northeast and their ore potential. J. Volcanol. Seismol. 2011, 5, 386-398. [CrossRef]

98. Sidorov, A.A.; Volkov, A.V.; Alekseev, V.Y. Zones of activation and volcanism. J. Volcanol. Seismol. 2013, 7, 185-195. [CrossRef] 
99. Marsh, J.H.; Stockli, D.F. Zircon U-Pb and trace element zoning characteristics in an anatectic granulite domain: Insights from LASS-ICP-MS depth profiling. Lithos 2015, 239, 170-185. [CrossRef]

100. Jackson, S.E.; Pearson, N.J.; Griffin, W.L.; Belousova, E.A. The application of laser ablation-inductively coupled plasma-mass spectrometry to in situ U-Pb zircon geochronology. Chem. Geol. 2004, 211, 47-69. [CrossRef]

101. Sláma, J.; Košler, J.; Condon, D.J.; Crowley, J.L.; Gerdes, A.; Hanchar, J.M.; Horstwood, M.S.A.; Morris, G.A.; Nasdala, L.; Norberg, $\mathrm{N}$.; et al. Plešovice zircon-A new natural reference Material for U-Pb and Hf isotopic microanalysis. Chem. Geol. 2008, 249, 1-35. [CrossRef]

102. Paton, C.; Hellstrom, J.; Paul, B.; Woodhead, J.; Hergt, J. Iolite: Freeware for the visualisation and processing of Mass spectrometric data. J. Anal. At. Spectrom. 2011, 26, 2508-2518. [CrossRef]

103. Petrus, J.A.; Kamber, B.S. VizualAge: A novel approach to laser ablation ICP-MS U-Pb geochronology data reduction. Geostand. Geoanal. Res. 2012, 36, 247-270. [CrossRef]

104. Kristoffersen, M.; Andersen, T.; Elburg, M.A.; Watkeys, M.K. Detrital zircon in a supercontinental setting: Locally derived and far-transported components in the Ordovician natal group, South Africa. J. Geol. Soc. 2016, 173, 203-215. [CrossRef]

105. Shishkin, V.A. Explanatory Notes for the State Geological Map of the USSR. Srednekolymsk Series. Sheet Q-56-XXVII-XXVIII (Korkodon). Scale 1:200 000; The USSR Ministry of Geology: Moscow, Russia, 1986. (In Russian)

106. Ludwig, K.R. ISOPLOT for MS-DOS, a Plotting and Regression Program for Radiogenic-Isotope Data, for IBM-PC Compatible Computers, Version 2.75; U.S. Geological Survey, Open-File Report: Reston, VA, USA, 1991; pp. 91-445.

107. Ludwig, K.R. On the treatment of concordant uranium-lead ages. Geochim. Cosmochim. Acta 1998, 62, 665-676. [CrossRef]

108. Shevchenko, V.M.; Shul'diner, V.I.; Kuzmin, V.K.; Belyatsky, B.V. New U-Pb data of isotope dating of metamorphic and Magmatic complexes of the Omolon Massif. In Transactions of the All-Russian Meeting "General Problems of the Precambrian Differentiation"; Poligraf: Apatites, Russia, 2000; pp. 280-282. (In Russian)

109. Shevchenko, V.M. Archean and Proterozoic of Omolon Massif. Petrology and Isotopic Age; NESC FEB RAS: Magadan, Russia, 2006. (In Russian)

110. Prokopiev, A.V.; Ershova, V.B.; Stockli, D.F. First data on the (U-Th)/He low-temperature thermochronology of detrital zircons (ZHe) from sedimentary rocks of the southern part of the Prikolyma terrane (Verkhoyansk-Kolyma folded area). In Problems of Tectonics of Continents and Oceans; GEOS: Moscow, Russia, 2019; pp. 141-144. (In Russian)

111. Prokopiev, A.V.; Toro, J.; Miller, E.L.; Gehrels, G.E. The paleo-Lena River-200 m.y. of transcontinental zircon transport in Siberia. Geology 2008, 36, 699-702. [CrossRef]

112. Gladkochub, D.P.; Donskaya, T.V.; Wingate, M.T.D.; Mazukabzov, A.M.; Pisarevsky, S.A.; Sklyarov, E.V.; Stanevich, A.M. A onebillion-year gap in the Precambrian history of the southern Siberian craton and the problem of the Transproterozoic supercontinent. Am. J. Sci. 2010, 310, 812-825. [CrossRef]

113. Shephard, G.E.; Müller, R.D.; Seton, M. The tectonic evolution of the Arctic since pangea breakup: Integrating constraints from surface geology and geophysics with Mantle structure. Earth Sci. Rev. 2013, 124, 148-183. [CrossRef] 